\title{
Terminal Pleistocene lithic variability in the Western Negev (Israel): Is there any evidence for contacts with the Nile Valley?
}

\author{
Alice Leplongeon ${ }^{1,2,3}$, A. Nigel Goring-Morris ${ }^{3}$ \\ 1. UMR CNRS 7194, Human \& Environment Department, Muséum national d’Histoire Naturelle - Université \\ Via Domitia Perpignan - Sorbonne Universités, 1 rue René Panhard, 75013 Paris, France. \\ Email: alice.leplongeon@mnhn.fr \\ 2. McDonald Institute for Archaeological Research, University of Cambridge, Downing Street, CB2 3ER \\ Cambridge, U.K. \\ 3. Institute of Archaeology, The Hebrew University of Jerusalem, Jerusalem 91905, Israel. \\ Email: nigel.goring-morris@mail.huji.ac.il
}

\begin{abstract}
:
At the end of the Pleistocene (25,000-15,000 BP), there is a shift to more arid conditions in the Negev and the Sinai corresponding to the Last Glacial Maximum. For the Nile Valley and the Levant, the lowering of the Mediterranean sea level, the expansion of the Sahara and the desiccation of some major eastern African lakes had important consequences on: (1) the general behaviour of the River Nile; (2) the landscape around the Nile Delta; and (3) sand dune mobilisation. Despite this shift to more arid conditions, there is abundant evidence for human occupation in the Egyptian Nile Valley and in the arid zone of the Southern Levant at this time. In addition, contacts between these two regions have sometimes been suggested, mainly by genetic studies, including early 'Back-to-Africa' dispersals.

This paper focuses on the analysis of six terminal Pleistocene (ca. 25,000-15,000 BP) lithic assemblages from the western Negev Desert dunes in Israel, attributed to the Early and Middle Epipalaeolithic. The analysis relies on the chaîne opératoire approach combined with attribute analysis that enables quantification of typo-technological differences. Results of this analysis allow comparisons with assemblages from the Egyptian Nile Valley analysed in the same way previously. This comparative analysis is then used to discuss hypotheses of potential technical diffusions between these two regions. Current archaeological evidence therefore does not support any contacts between populations between the Levant and the Nile Valley at the end of the Pleistocene.
\end{abstract}

Keywords: Negev Desert; Epipalaeolithic; lithic analysis; dispersal hypotheses

Published by the School of History, Classics and Archaeology, University of Edinburgh ISSN: 2055-0472. URL: http://journals.ed.ac.uk/lithicstudies/ 


\section{Introduction}

\subsection{Terminal Pleistocene dispersals out of and back into Africa}

The Negev and Sinai together represent a key-location in discussions of dispersal events of modern humans out-of and back-into Africa. However, the number, routes and timing of these dispersals are highly controversial (Nielsen et al. 2017). Archaeological evidence supporting the 'northern' route out of Africa through the Nile Valley is sparse and debated (Groucutt et al. 2015; but see Goder-Goldberger 2013; Goder-Goldberger et al. 2016; GoderGoldberger et al. 2017). Most evidence for Late Pleistocene connections between the Nile Valley, North Africa and the Levant, including back-to-Africa dispersals, through or from the Levant, at the end of the Pleistocene derive from genetic studies (Forster et al. 2007; Henn et al. 2012; Hodgson et al. 2014; Olivieri et al. 2006; Pennarun et al. 2012; Underhill et al. 2001). Recently published results from ancient DNA at Taforalt (Morocco), on skeletons dated to $\sim 15,000$ cal BP, provide direct evidence for genetic interactions across Africa and Eurasia (with one third of their ancestry deriving from western and eastern Africa, and two thirds from the Near East) (Loosdrecht et al. 2018).

However, archaeological evidence for dispersals or contacts between the two regions (Nile Valley and Levant) remains sparse and there is a lack of systematic comparisons of assemblages between the Levant and the Nile Valley. Relying on the presence of blade technology, connections between the Levant and the Nile Valley were suggested (Bar-Yosef 1987; Bar-Yosef 2013; Bar-Yosef 2017). However, the sites of Nazlet Khater 4 and Taramsa 1 are the only Upper Palaeolithic sites securely dated to Marine Isotope Stage 3 (MIS3) in the Lower Nile Valley and both represent special function quarry sites with few diagnostic tools (Leplongeon \& Pleurdeau 2011; Vermeersch et al. 2002), lacking the el-Wad points and retouched bladelets characteristic of the Levantine Early Ahmarian (Bar-Yosef \& Belfer 1977; Goring-Morris \& Davidzon 2006). The lack of sites from this period in the Nile Valley hamper any thorough comparisons between these two areas, and more data are needed to discuss contacts during the Late Pleistocene.

The following period, corresponding to Marine Isotope Stage (MIS) 2, is characterised by a significant increase in the numbers of sites, both in the Nile Valley and the Negev and Sinai. Some evidence may suggest an extension of the Mushabian and Ramonian Epipalaeolithic industries of the southern Levant as far west as the apex of the Nile Delta (Debono 1948; Schmidt 1996; Tassie 2014). The unsystematic collections there include what appear to be Middle Epipalaeolithic Mushabian arch backed and scalene bladelets with microburin technique. However, no detailed comparisons were made between these two areas.

Although the Nile Valley and Sinai-Negev are obvious routes out-of and back-into Africa, very little is known of interactions between these two areas during the later Pleistocene. This paper aims to contribute to this issue by comparing lithic assemblages from the Epipalaeolithic of the Negev with assemblages from the Late Palaeolithic of the Nile Valley, both occurring during MIS 2.

\subsection{The Early and Middle Epipalaeolithic of the Negev}

The beginning of the Epipalaeolithic (EP) roughly coincides with the start of the Last Glacial Maximum (LGM) (ca. 23,000 cal BP). The palaeoenvironmental record indicates a steppic environment in the Negev throughout the Late Pleistocene (Enzel et al. 2008; Baruch \& Goring-Morris 1997; Goring-Morris 2017). Speleothem bearing karstic caves of the northern Negev Desert indicate major periods of speleothem deposition, corresponding to humid phases between 76-25ka and 23-13ka (Vaks et al. 2006). A phase of dune advance and dune formation, indicating a west-east vector of winds, is documented in northern Sinai and 
the western Negev, beginning at $30,000-25,000$ BP with a major phase of dune activity between 20,000-10,000 cal BP in two main phases (Ben-David \& Yair 2008; Enzel et al. 2008; Goring-Morris \& Goldberg 1990; Roskin \& Tsoar 2017). This probably indicates much stronger W-SW winds than today (Enzel et al. 2008). Despite reduced rainfall in the northern Sinai and the western Negev during the LGM, dune encroachment would have caused seasonal of damming of drainage basins, and the creation of ponds and lakes at the dune margins, therefore attracting animals and humans (Goring-Morris \& Goldberg 1990; GoringMorris 2017; Roskin et al. 2014; Roskin \& Tsoar 2017). This would explain the marked increase in the number of sites (and thus presumably in population density) in the western Negev at that time (Goring-Morris \& Belfer-Cohen 1997).

The Epipalaeolithic is characterized by a trend towards the microlithisation of chipped stone artefacts (Belfer-Cohen \& Goring-Morris 2002) an increase in the number of occupations despite colder and more arid climatic conditions (Goring-Morris et al. 2009) and increasing territoriality, as seen in the development of style in the lithic assemblages (GoringMorris \& Belfer-Cohen 1997). Other characteristics are the emergence and intensification in the use of grinding stones (Peterson 1999; Wright 1994), funerary behaviours, aggregation sites, mobile art and ornaments (Goring-Morris 1995; Goring-Morris \& Belfer-Cohen 1997; Maher et al. 2012).

The Southern Levantine EP can be divided into three phases: Early, Middle and Late EP, each comprising several lithic industries (Table 1). Geographic distributions of these industries (contractions and expansions) may be linked to climatic changes (Belfer-Cohen \& Goring-Morris 2014; Goring-Morris 1987; Goring-Morris 1995; Goring-Morris et al. 2009). In particular, the Middle EP Geometric Kebaran, Mushabian and Ramonian industries are documented in the Negev and Sinai during the Bølling-Allerød (Bar-Yosef \& Phillips 1977: 255-260; Goring-Morris 1987); in the case of the Mushabian and Ramonian perhaps extending as far west as the apex of the Nile Delta (Debono 1948; Schmidt 1996; GoringMorris \& Belfer-Cohen 1997; Belfer-Cohen \& Goring-Morris 2014). The unsystematic collections there include what appear to include Middle Epipalaeolithic Mushabian arch backed and scalene bladelets with microburin technique. Generally speaking, the Negev Early and Middle EP sites are characterised by relatively small, short-term occupations, often associated with one or more hearths.

Table 1. Entities and approximate date ranges for the Epipalaeolithic of the Negev (Dates after Goring-Morris 2017). Abbreviations: * Entities with habitual use of the microburin technique.

\begin{tabular}{lll}
\hline Period & Entities & $\begin{array}{l}\text { Approximate date ranges } \\
\text { (cal BP) }\end{array}$ \\
\hline Early Epipalaeolithic & Masraqan (Late Ahmarian) & $\sim 25,000-20,000$ \\
& Kebaran & $\sim 23,000-18,500$ \\
& Nizzanan * & $\sim 20,000-18,500$ \\
\hline Middle Epipalaeolithic & Geometric Kebaran & $\sim 19,000-15,000$ \\
& Mushabian - Early Ramonian * & $17,750-15,000$ \\
\hline Late Epipalaeolithic & Terminal Ramonian - Early Natufian * & $15,000-13,500$ \\
& Late Natufian * & $13,500-12,500$ \\
& Harifian * & $12,500-11,650$ \\
\hline
\end{tabular}

Lithic variability in the EP of the Levant is apparent typologically and technologically, including the presence or absence of the microburin technique in microlith production (Goring-Morris 1987; Goring-Morris 1995; Goring-Morris et al. 1998; Marder 2002). Detailed refitting studies of numerous Epipalaeolithic lithic assemblages in the Negev 
indicated that, despite a few inter-site and inter-industry differences, the entities there are characterised by a shared general technological homogeneity (Marder 2002). The main chaîne opératoire is oriented towards the production of microliths. It is further characterised by serial blade(let) production from single platform cores on locally available flint nodules. A gradual shift is demonstrated from the 'Upper Palaeolithic volumetric concept', defined by narrow fronted ('N-fronted') cores, reduced on their narrow front and used to produce standardised narrow bladelets (Goring-Morris \& Davidzon 2006), to the 'Epipalaeolithic volumetric concept', defined by wide fronted ('W-fronted') and sub-pyramidal cores, with the exploitation of their wide front for the production of less regular wide bladelets (Davidzon \& Goring-Morris 2003: 158). Core maintenance is minimal, usually consisting in the blunting of the cores' removal surfaces, and the removal of a few atypical core tablets and crested products, and sometimes an opposed supporting platform. In addition to typological variability amongst the Epipalaeolithic chipped stone entities, two stylistic variations are found, namely the absence or systematic use of the microburin technique (Goring-Morris 1987).

\subsection{The Late Palaeolithic of the Egyptian Nile Valley}

The later part of the Pleistocene ( 25,000-10,000 BP) in Upper and Middle Egypt corresponds to an exceptional increase in the number of sites, used as a proxy for population density (see Figure 1). At a time when hyper-aridity seems to characterise most of northeastern Africa, such 'demographic packing' may be explained by the Nile valley playing the role of a 'refugium'.

Two competing models exist for the behaviour of the Nile river and local palaeoenvironmental conditions during the LGM: a river with braided channels and a much lower discharge than today (Wendorf \& Schild 1989; Schild \& Wendorf 2010); or the formation of lakes created by sand dunes damming the Nile (Vermeersch 2006; Vermeersch \& Van Neer 2015). In both models, there are few if any Terminal Pleistocene sediments preserved in the northern portion of the Nile Valley and its Delta (Butzer 1997: 167; Hendrickx \& Vermeersch 2000; Sandford 1936; Wendorf \& Schild 1989). Archaeologically, evidence for human occupation during MIS2 in the Nile Valley comes mainly from near Qena in Middle Egypt (e.g. Vermeersch 2000; Vermeersch 2002), from Upper Egypt (Wendorf \& Schild 1976; Wendorf \& Schild 1989; Schild \& Wendorf 2010), as well as from Upper Nubia in Sudan (Osypiński \& Osypińska 2016). Additionally, arid conditions with high Saharan dust input in the Nile margins are documented until ca. 14,600 cal BP (Revel et al. 2010; Revel et al. 2015). Nevertheless, considering that the nearby Sinai and Negev deserts have yielded abundant evidence for human occupation during MIS2 (see above), local conditions may have enabled punctuated occupations of the Delta during that period.

Archaeological data at these sites reflect dense occupations, most of them oriented towards fish exploitation, such as at Makhadma 4 (Vermeersch et al. 2000) or Wadi Kubbaniya (Wendorf \& Schild 1989). There is a great variability in lithic assemblages, which led to the definition of numerous lithic industries (e.g., Kubbaniyan, Afian, Silsilian, Fakhurian, etc.), some of which have the particularity of retaining some Middle Palaeolithic Middle Stone Age characteristics, such as the Levallois method. No site, securely dated to this period, is known in the Delta region. Further south, a recently excavated site in Sudan, Affad 23, has yielded an occupation level dated to $15-16 \mathrm{ka}$, associated with a faunal assemblage dominated by medium to large-size mammals and a lithic assemblage with full Middle Stone Age characteristics, including Levallois methods (Osypiński \& Osypińska 2016; Osypińska \& Osypiński 2016). This raises further questions on the nature of the variability at the end of the Pleistocene in the Nile Valley and possibly complex population dynamics at that time. 


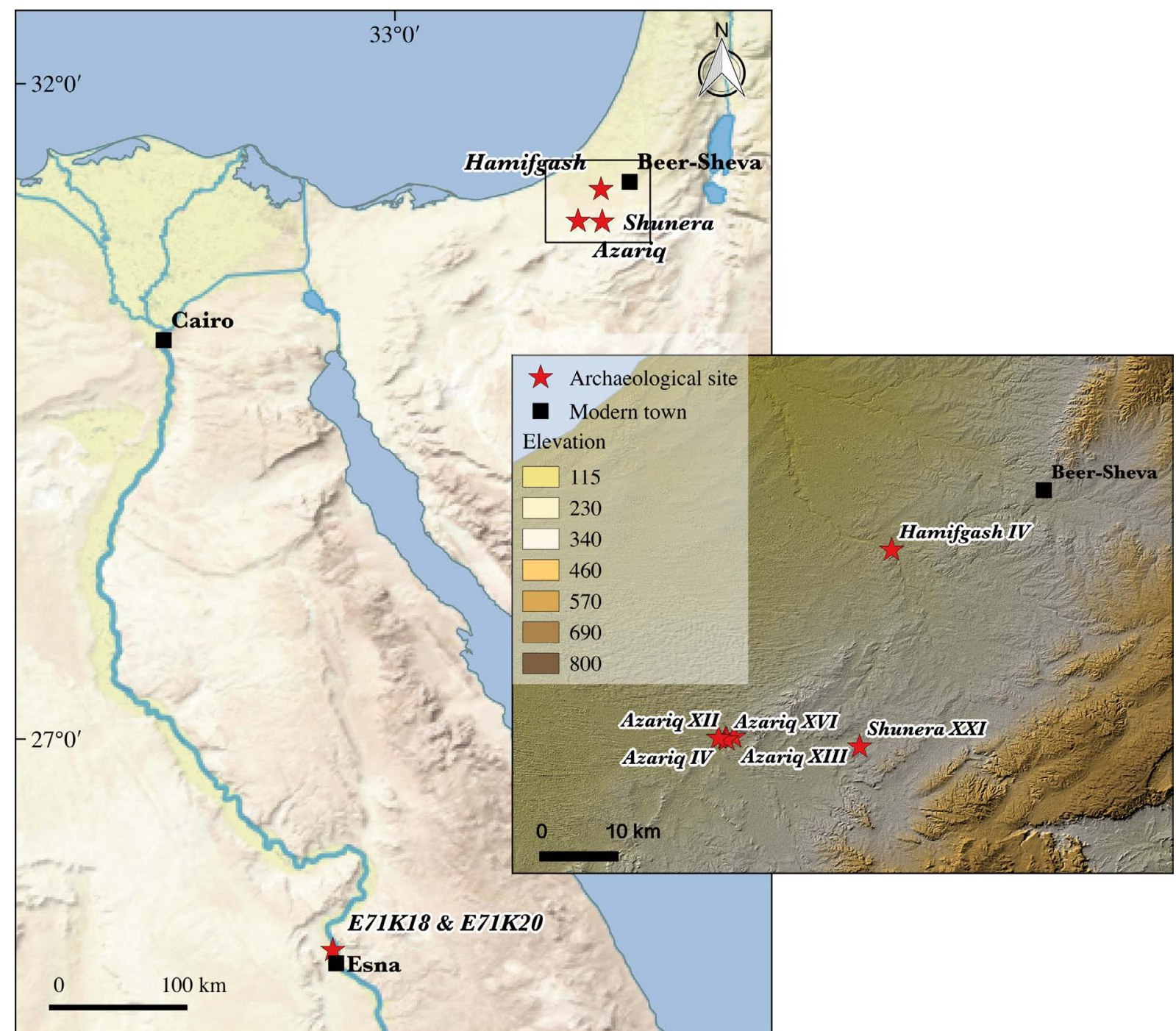

Figure 1. Location of sites mentioned in the text. Elevation map after SRTM 1 Arc-second Global elevation data available from the U.S. Geological Survey. Base map made using Natural Earth Data. Both made with QGIS.

\section{Main research objectives}

This short review contributes to highlighting several problems that have hampered testing hypothetical connections between the Levant and the Nile Valley: the lack of archaeological data, particularly in the northern part of the Nile Valley, as any posited sites are likely to be deeply buried within the delta sediments due to latter aggradation as sea levels rose following the LGM, as well as the debated palaeoenvironmental reconstructions, particularly in the lower Nile Valley. In addition, different methods, periodisation, terminologies and typologies were used to describe lithic assemblages, e.g., Epipalaeolithic (EP) in the Levant vs. Late Palaeolithic (LP) in the Nile Valley. While recent genetic studies all seem to point to major Pleistocene interactions between the Levant and northeastern Africa, the archaeological evidence remains sparse.

The EP of the Negev and northern Sinai is relatively well known (Goring-Morris 1987). Characteristics of the lithic assemblages have mainly been described following a general typo-technological viewpoint (i.e., on morphotypes of the mostly microlithic components and the absence or presence of the microburin technique), supplemented by technological analyses deriving from refitting studies (see above). Although the combination of both approaches allows thorough characterisation of EP techno-typology, in the absence of similar refitted assemblages in the Nile Valley, these data cannot be easily used in the frame of detailed 
comparative analyses, where quantification of differences and similarities between assemblages are necessary.

This paper thus aims to describe and technologically analyse assemblages from the EP of the Negev, relying on both the concept of chaîne opératoire and the use of attribute analysis to quantify technological differences. By applying the same methods used to describe Late Palaeolithic lithic assemblages from the Nile Valley (Leplongeon 2017), this should enable: (1) examination of lithic variability within the EP of the Levant from a different perspective; and (2) systematic comparisons of Levantine assemblages with assemblages from adjacent regions and further investigate hypotheses of technical diffusion.

\section{The sites}

\subsection{Negev sites}

The six assemblages analysed herein are assigned to one each of the entities assigned on techno-typological grounds to the Early and Middle Epipalaeolithic in the Negev and Sinai (Goring-Morris 1987) (Table 2).

The assemblages derive from systematic excavations or collections conducted by one of us in the framework of the Emergency Archaeological Survey of the Negev (Figure 1). All sites are located at the margins of the north Sinai-western Negev erg (longitudinal dune), in or deflating from sandy contexts. The sites were excavated using a $50 \mathrm{~cm}$ grid and sieved through a $3 \mathrm{~mm}$ mesh. Most are small, partially deflated ephemeral campsites with one or more hearths. They were almost completely excavated, with the exception of Azariq XII and Shunera XXI. The lithic assemblages are fresh and retain spatial integrity, as reflected in a systematic refitting program, with conjoin rates between $10-24 \%$ of the tools, cores and debitage of the studied assemblages (Goring-Morris et al. 1998; Marder 2002). Raw materials are readily available in nearby Eocene outcrops, or from nearby wadis as nodules, pebbles or cobbles washed downstream from the direction of the Negev highlands.

The Azariq sites are located adjacent to the confluence of Nahal Nizzana and Nahal Lavan, major tributaries draining the central Negev highlands via Wadi el-Arish to the Mediterranean. The Shunera assemblages are located near a dune-blocked seasonal playa or palaeolake ca. $15 \mathrm{~km}$ northeast of the Azariq area (Goring-Morris 1993), while Hamifgash is located at the confluence of Nahal Besor and Nahal Beersheva also draining the Negev highlands. Organic preservation is notoriously poor in the sandy soils of the Negev and Sinai, so that only mostly unidentifiable bone fragments, occasional marine mollusks and small fragments of charcoal were recovered. Few of the analysed sites provided reliable radiometric dates, so date estimates are based on those from the same entities elsewhere in the Southern Levant (Belfer-Cohen \& Goring-Morris 2014; Goring-Morris \& Belfer-Cohen 2017). The sites are described below in chronological order, from earliest to latest. 
Table 2. Raw counts by class of the studied lithic assemblages (data from Goring-Morris 1987; Goring-Morris et al. 1998; Marder 2002).

Abbreviations: Az. = Azariq, Ham. $=$ Hamifgash, Shun. $=$ Shunera

\begin{tabular}{|c|c|c|c|c|c|c|}
\hline Lithic Category & $\begin{array}{c}\text { Az. XIII } \\
\text { Masraqan }\end{array}$ & $\begin{array}{c}\text { Az. IV } \\
\text { Kebaran }\end{array}$ & $\begin{array}{l}\text { Ham. IV } \\
\text { Nizzanan }\end{array}$ & $\begin{array}{c}\text { Az. XVI } \\
\text { Geometric Kebaran }\end{array}$ & $\begin{array}{c}\text { Az. XII } \\
\text { Mushabian }\end{array}$ & $\begin{array}{l}\text { Shun. XXI } \\
\text { Ramonian }\end{array}$ \\
\hline Primary elements & 503 & 91 & 336 & 729 & 636 & 371 \\
\hline$\%$ assemblage & $4.8 \%$ & $2.2 \%$ & $6.7 \%$ & $7.8 \%$ & $5.1 \%$ & $3.7 \%$ \\
\hline Flakes \& fragments & 1118 & 1165 & 556 & 2528 & 1636 & 1053 \\
\hline$\%$ assemblage & $10.6 \%$ & $28.5 \%$ & $11.0 \%$ & $27.0 \%$ & $13.0 \%$ & $10.6 \%$ \\
\hline Blade(let)s \& fragments & 1677 & 482 & 471 & 2350 & 1872 & 2521 \\
\hline$\%$ assemblage & $15.9 \%$ & $11.8 \%$ & $9.4 \%$ & $25.1 \%$ & $14.9 \%$ & $25.3 \%$ \\
\hline Core trimming elements (CTE) & 324 & 99 & 170 & 147 & 261 & 74 \\
\hline$\%$ assemblage & $3.1 \%$ & $2.4 \%$ & $3.4 \%$ & $1.6 \%$ & $2.1 \%$ & $0.7 \%$ \\
\hline incl. core tablets & 85 & 19 & 17 & 12 & 45 & 5 \\
\hline$\% C T E$ & $26.2 \%$ & $19.2 \%$ & $10.0 \%$ & $8.2 \%$ & $17.2 \%$ & $6.8 \%$ \\
\hline incl. ridge & 120 & 41 & 29 & 33 & 29 & 18 \\
\hline$\%$ CTE & $37.0 \%$ & $41.4 \%$ & $17.1 \%$ & $22.4 \%$ & $11.1 \%$ & $24.3 \%$ \\
\hline Burin spalls & 17 & 10 & 10 & 10 & 16 & 7 \\
\hline$\%$ assemblage & $0.2 \%$ & $0.2 \%$ & $0.2 \%$ & $0.1 \%$ & $0.1 \%$ & $0.1 \%$ \\
\hline Cores & 40 & 18 & 29 & 32 & 73 & 26 \\
\hline$\%$ assemblage & $0.4 \%$ & $0.4 \%$ & $0.6 \%$ & $0.3 \%$ & $0.6 \%$ & $0.3 \%$ \\
\hline Retouched tools & 1188 & 230 & 336 & 1251 & 1353 & 1165 \\
\hline$\%$ assemblage & $11.3 \%$ & $5.6 \%$ & $6.7 \%$ & $13.4 \%$ & $10.8 \%$ & $11.7 \%$ \\
\hline Microburin technique related pieces & 0 & 2 & 262 & 30 & 350 & 594 \\
\hline$\%$ assemblage & $0.0 \%$ & $0.0 \%$ & $5.2 \%$ & $0.3 \%$ & $2.8 \%$ & $6.0 \%$ \\
\hline Chips & 5569 & 1150 & 2772 & 2123 & 6278 & 4062 \\
\hline$\%$ assemblage & $52.9 \%$ & $28.2 \%$ & $55.1 \%$ & $22.7 \%$ & $49.9 \%$ & $40.8 \%$ \\
\hline Chunks & 96 & 838 & 91 & 164 & 94 & 86 \\
\hline$\%$ assemblage & $0.9 \%$ & $20.5 \%$ & $1.8 \%$ & $1.8 \%$ & $0.7 \%$ & $0.9 \%$ \\
\hline Total & 10532 & 4085 & 5033 & 9364 & 12569 & 9959 \\
\hline
\end{tabular}




\subsubsection{Azariq XIII}

Azariq XIII (Az XIII) is attributed to the Early Epipalaeolithic Masraqan (ca. 25,50020,000 cal BP), and extended over ca. $75 \mathrm{~m}^{2}$ (Goring-Morris 1995; Goring-Morris et al. 1998). While largely deflated, the probable presence of the outline of a brush hut indicate it has largely retained spatial integrity (Goring-Morris \& Belfer-Cohen 2003; Goring-Morris \& Belfer-Cohen 2008) (Table 1). The lithic assemblage is characterised by a standardised techno-typology, with the main chaîne opératoire oriented towards the choice of good quality discoidal flint nodules sometimes split into two (Figure 2a, b, which conjoin) or introduced as ready-made cores on large flakes or blades (Figure 2c). The narrow side was used as the removal surface for series of elongated, convergent bladelet blanks. These $\mathrm{N}$-fronted cores were maintained by core tablet removals and a few ridge blades. The bladelets were finely retouched (Ouchtata) along one lateral edge (Figure 2f). A separate chaîne opératoire to produce massive blanks and tools (end-scrapers) was also noted.

\subsubsection{Azariq IV}

The small, ca. $25 \mathrm{~m}^{2}$, ephemeral site of Azariq IV (Az IV) is attributed to the Early Epipalaeolithic early Kebaran (ca. 22,000-18,500 cal BP; (Belfer-Cohen \& Goring-Morris 2014; Goring-Morris \& Belfer-Cohen 2017). Though mostly deflated, it included a hearth. The lithic assemblage is dominated by single platform cores $(>50 \%)$ for the production of blade(let)s (Figure 3). Non-geometric microliths, mainly backed micropoints (Bar-Yosef 1970: 162-164) dominate (>85\%) the retouched tools. Refitting enabled the reconstruction of the chaîne operatoire that is similar to, but less homogeneous than that of Azariq XIII, with single platform cores mainly exploited on their narrow elongated side ( $\mathrm{N}$-fronted cores), and primarily oriented towards the production of more robust bladelets (Goring-Morris et al. 1998).

\subsubsection{Hamifgash IV}

Hamifgash IV (Ham IV) is a small, $30 \mathrm{~m}^{2}$, in situ Early Epipalaeolithic Nizzanan occurrence (ca. 20,000-18,500 cal BP) eroding from a horizon of sandy-silty fluvially reworked sediments. Immediately adjacent stratigraphic correlations place it below, i.e., predating, Middle Epipalaeolithic Geometric Kebaran and Ramonian occurrences (GoringMorris 1987: 153; Marder 2002). Charcoal from one of two hearths provided two dates, one clearly aberrant. The main chaîne opératoire includes relatively narrow single platform cores ( 75\%) and, less commonly, opposed platform cores ( 25\%) for the production of unstandardized elongated microlith blanks. In the latter case, one platform is dominant, while the other is considered to be supporting to ensure convexity of the removal surface. The blanks were transformed mainly into arch-backed bladelet or scalene triangle forms, using the microburin technique (Figure 4). A few microgravette points are also characteristic (GoringMorris 1987).

\subsubsection{Azariq XVI}

Azariq XVI (Az XVI) is a partially deflated Geometric Kebaran (ca. 18,500-15,000 cal BP) site, covering ca. $50 \mathrm{~m}^{2}$ in an interdunal basin and yielded a hearth (Belfer-Cohen \& Goring-Morris 2014). Ochre stains were noted on several blades. The large assemblage fits with the general Geometric Kebaran characteristics (Table 2), with a majority of single platform cores for the production of blades or bladelets, maintained by the removals of ridge blades and core tablets. Geometric microliths (trapezes and rectangles) dominate the 
retouched tools $(>70 \%)$ (Figure 5$)$. There is a very low number of microburins $(n=46)$, more than half being Krukowski variants (Goring-Morris 1987). Refitting enabled identification of one main chaîne opératoire for geometric microliths and endscrapers and two other minor chaînes opératoires, one for endscrapers and the other for the off-site production of massive tools (Marder 2002).

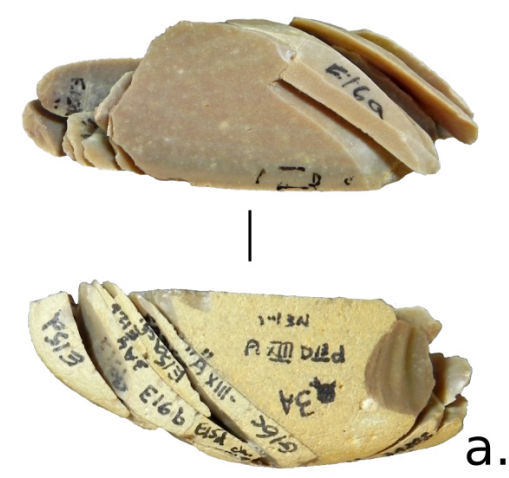

a.
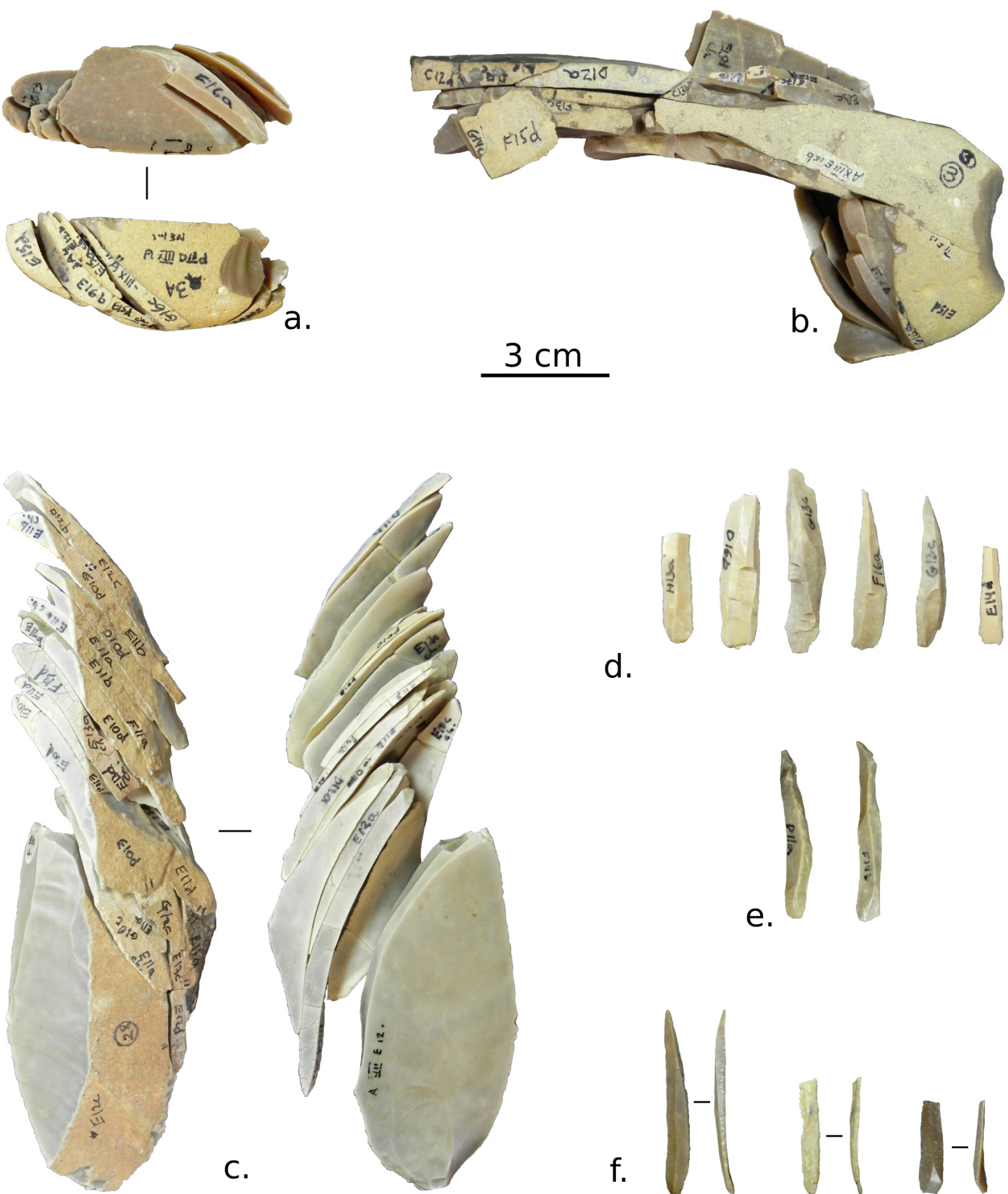

d.

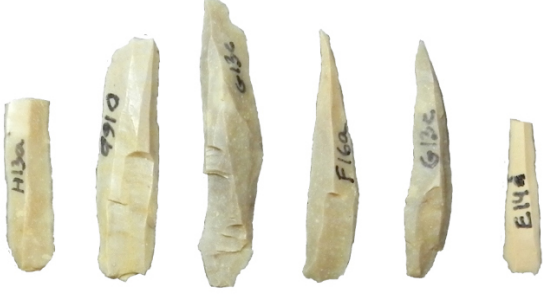

Figure 2. Azariq XIII - lithic artefacts. (a-c) refits - a refits with b, bladelet cores, (d) elongated blanks, (e) crested blades, (f) Ouchtata retouched bladelets. 

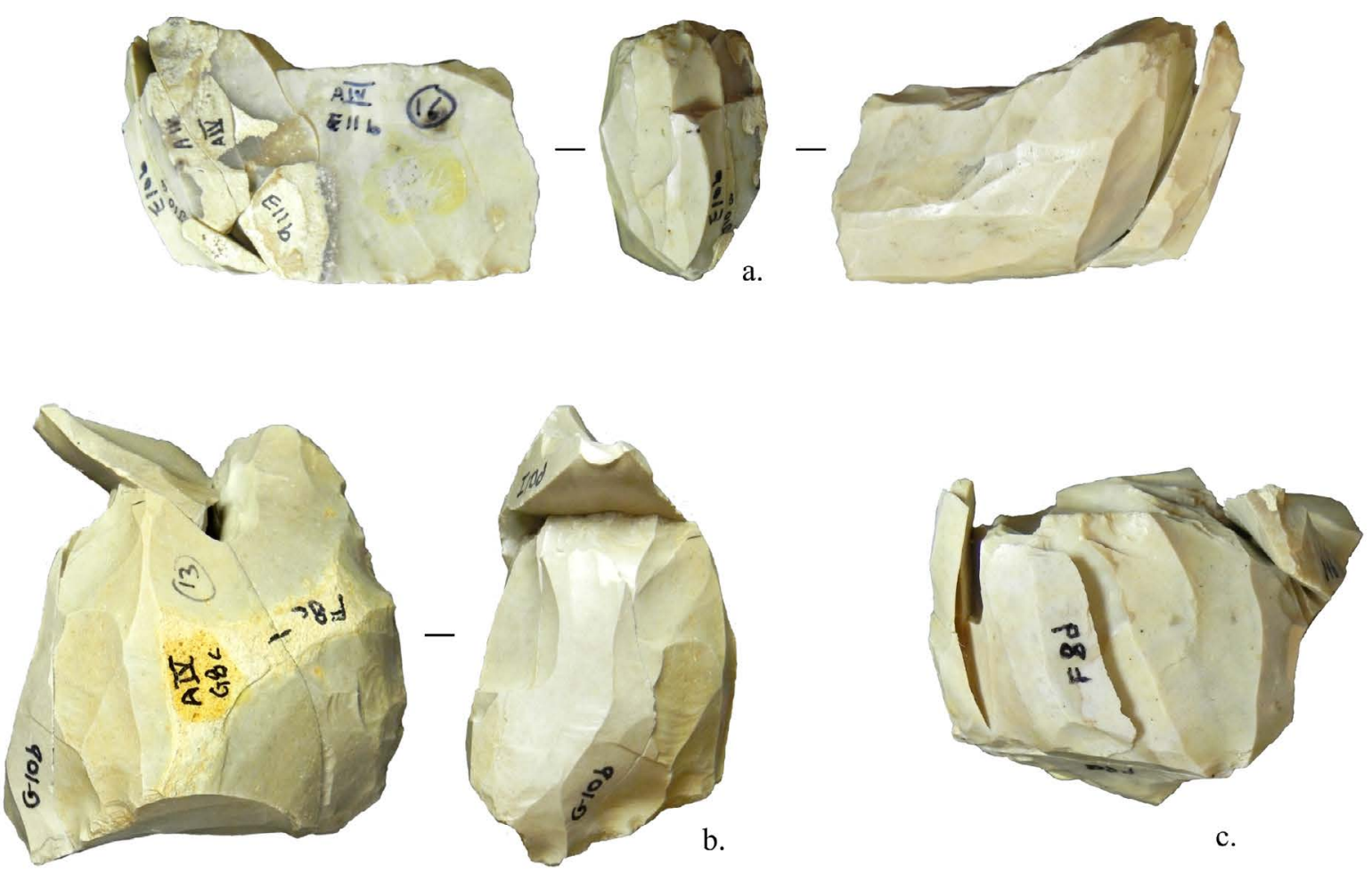

c.
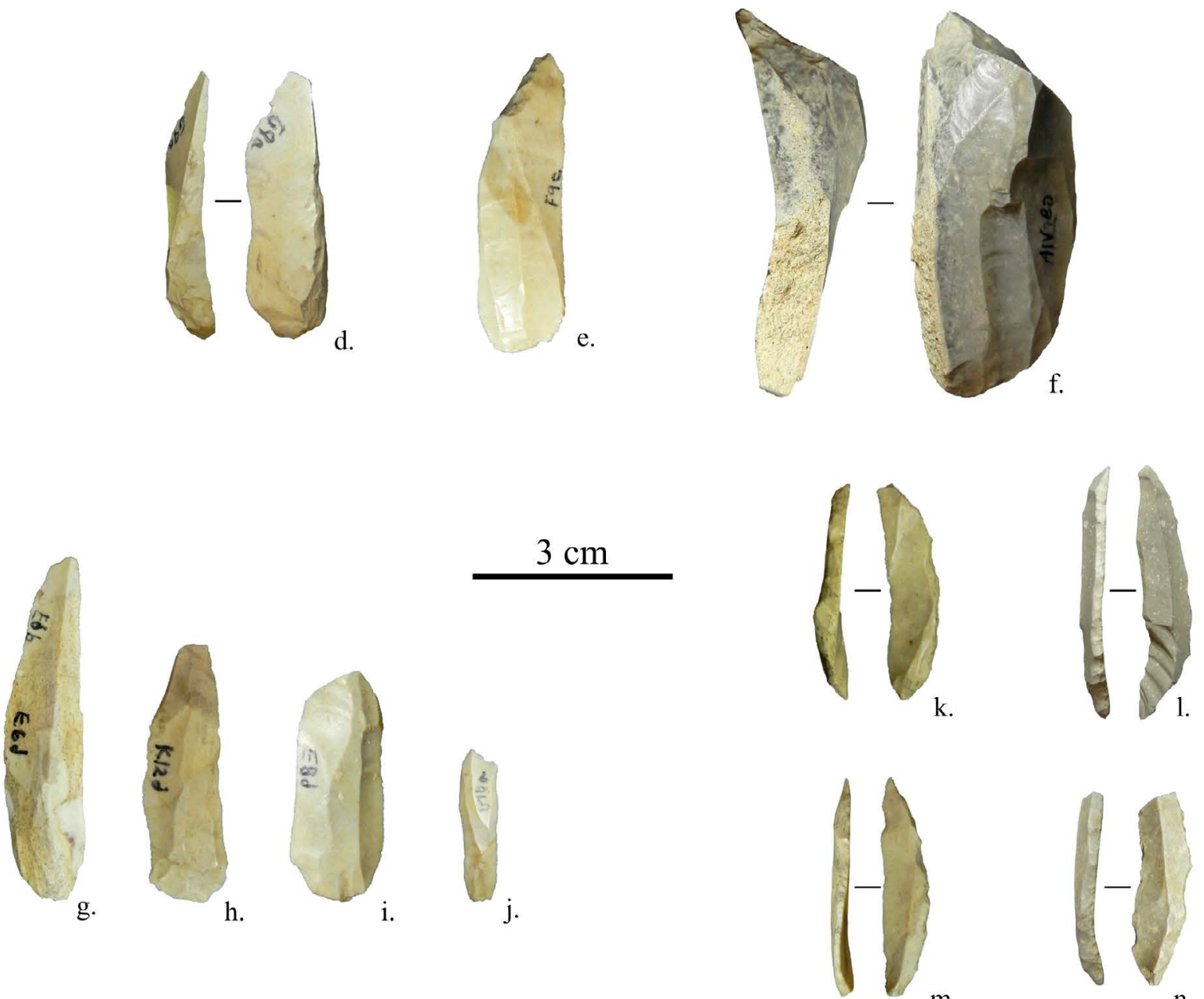

Figure 3. Azariq IV - lithic artefacts. (a-c) refits of cores with blade(lets), (a) on split; (d-f) core trimming elements; (g-j) elongated blanks, (k-n) backed micropoints. 

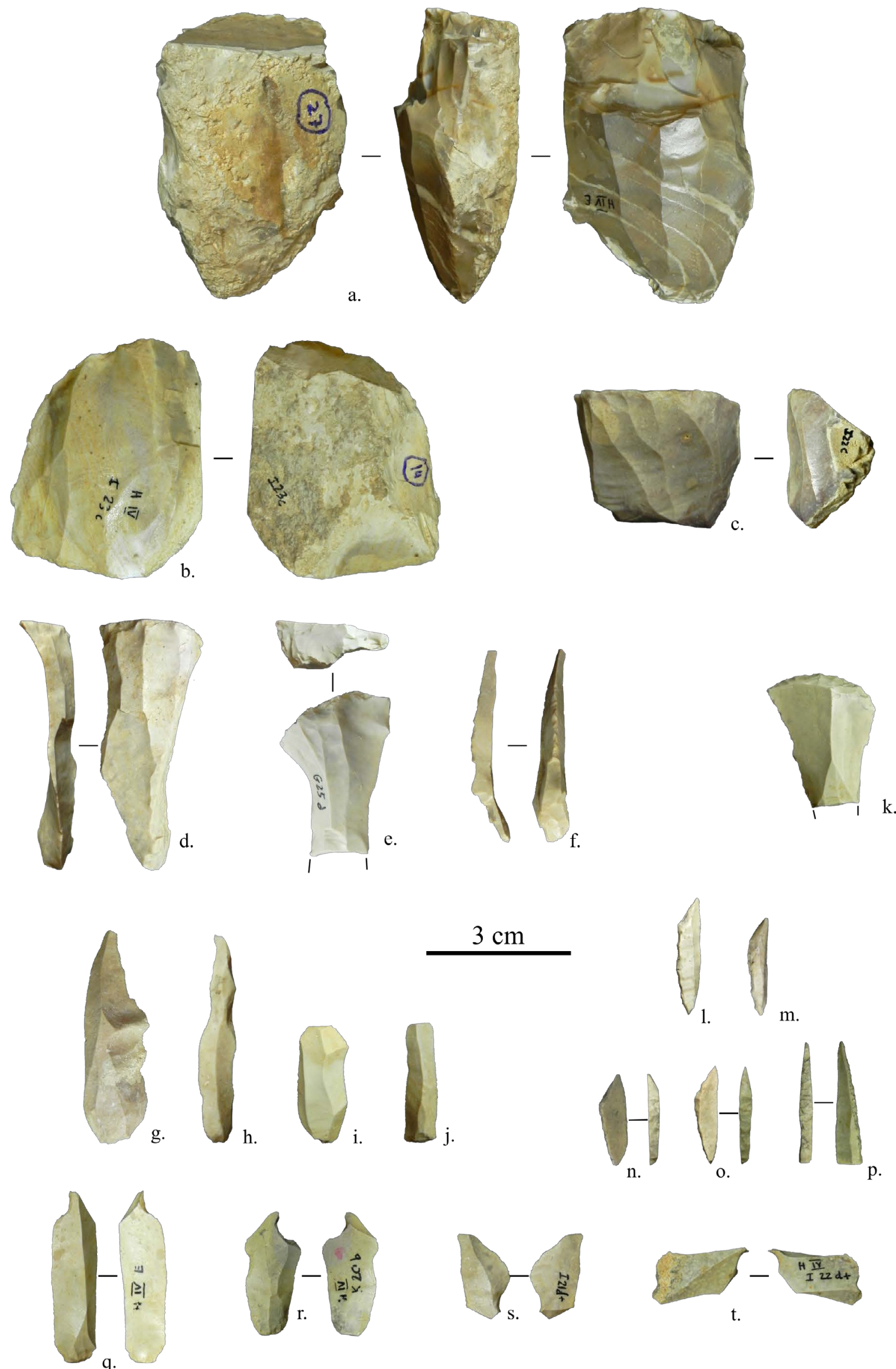

t.

Figure 4. Hamifgash IV - lithic artefacts. (a-c) cores, (d-f) core trimming elements, (g-j) elongated blanks, (k) end-scraper, (l-0) arch-backed bladelets, (p) 'microgravette' point, (a-t) microburins. 

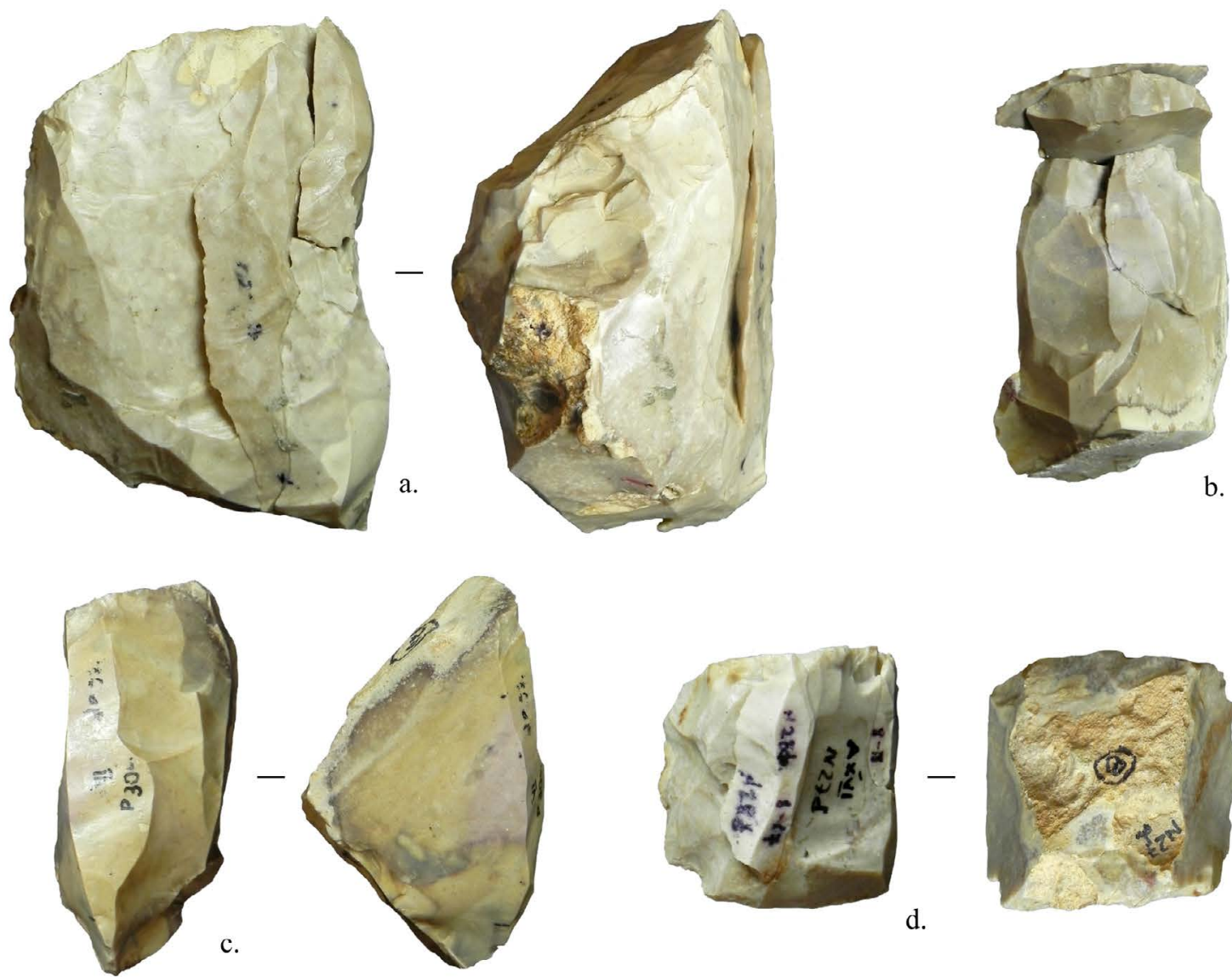

d.

b.

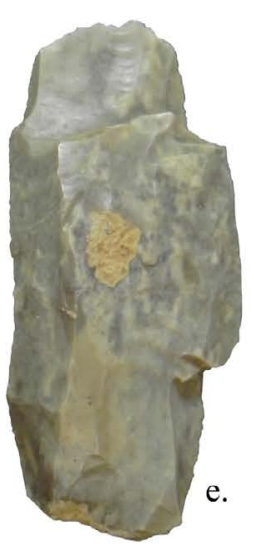

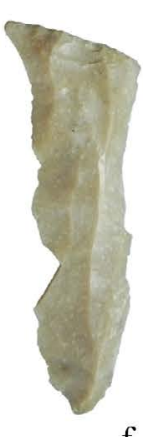

f.
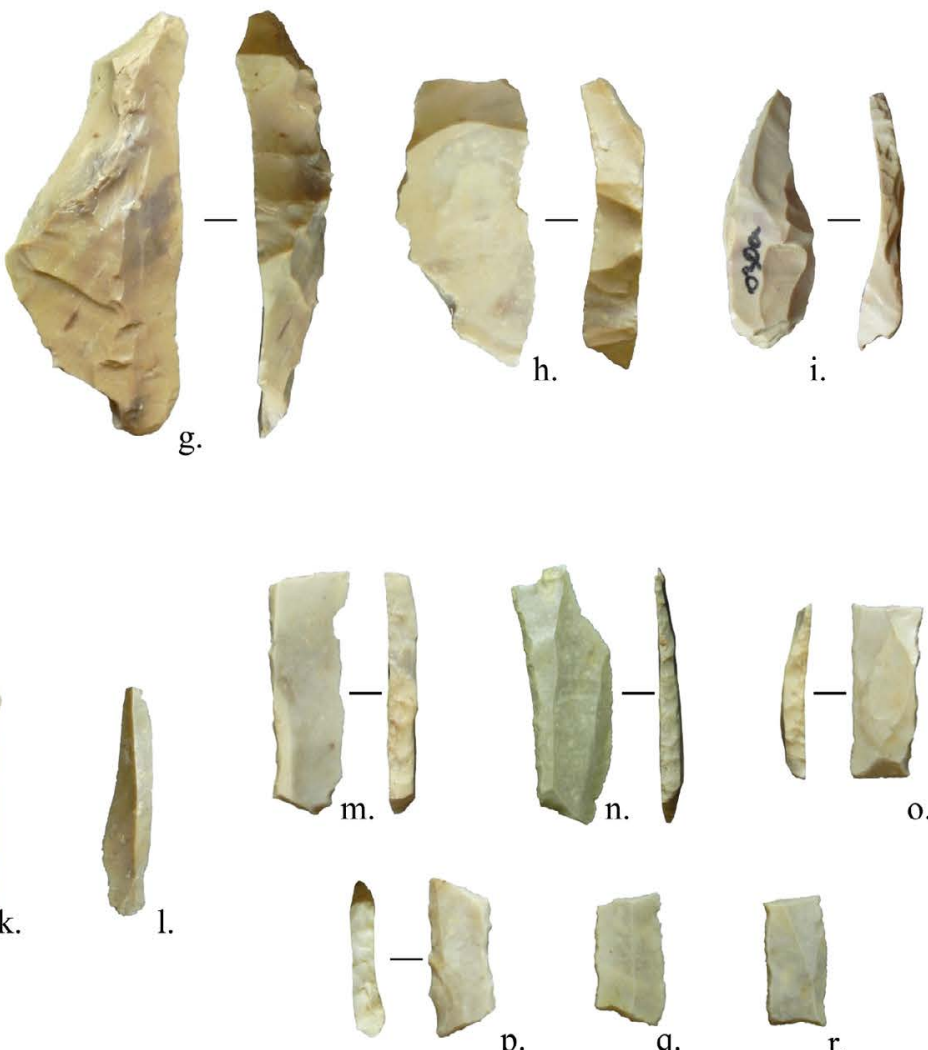

Figure 5. Azariq XVI - lithic artefacts. (a-d) cores, (e-i) core trimming elements, (j-l) elongated blanks, (m-r) geometric microliths (trapezes and rectangles). 


\subsubsection{Azariq XII}

Azariq XII (Az XII) is an extensive, partially deflated Mushabian (ca. 17,750-15,000 cal BP) site within a palaeosol, extending over $>100 \mathrm{~m}^{2}$. Two hearths were present within the excavated area (and at least two others were present), each accompanied by quantities of burnt stones interpreted as roasting pits (Goring-Morris 1987; Goring-Morris \& Belfer-Cohen 2003). The main chaîne opératoire of the abundant assemblage was focused on the production of microliths, although three to four other minor chaînes opératoires were also noted (Marder 2002). Contrary to other Mushabian assemblages, opposed platform cores are the dominant form at Azariq XII (Goring-Morris 1987: 176). Elongated blanks were transformed into arch-backed or scalene bladelets (while some superficially look like lunates, the proximal ends are not modified) and fewer blunt backed bladelets, with only the first category manufactured using the microburin technique (Goring-Morris 1987; Marder 2002)(Figure 6).

\subsubsection{Shunera XXI}

Shunera XXI (Sh XXI) is a large $\left(>80 \mathrm{~m}^{2}\right)$ partially excavated Ramonian site deflating from a dune (Goring-Morris 1987). Within the excavated area four hearths were identified, one with considerable quantities of burnt stones; a charcoal date of $12100 \pm 140$ BP (14141 \pm 294 cal BP) is considered too young. The abundant assemblage was mainly made from flint but also from translucent chalcedony ( $25 \%$ of artefacts). The main chaîne opératoire focused on blade-let blanks from single-platform, pyramidal cores intended for Ramon points manufactured by the microburin technique (Goring-Morris 1987; Marder 2002) (Figure 7). Minor off-site or on-site chaînes opératoires for the production of medium-sized tools such as endscrapers were also noted.

\subsection{The Nile Valley sites: E71K18 and E71K20}

Cultural entities of the Nile Valley during MIS2 are attributed to the Late Palaeolithic (LP). LP sites are concentrated in Upper Egypt and in the Egyptian and Sudanese Nubia (Schild \& Wendorf 2010). This is the result of both the history of research in the area, strongly linked with the construction of the Aswan dam, and with the geomorphological characteristics of the Nile at that time (see above).

Here we focus on two sites, E71K18 and E71K20, located near Esna, in Upper Egypt, ca. $600 \mathrm{~km}$ distant from the Negev-Sinai (Figure 1). They are attributed to the Afian and Silsilian industries, respectively.

E71K18 was first described by Wendorf and Schild (1976). It is composed of five small deflated surface concentrations (localities A to E). The deflated surface is associated with a pond sediment, which, according to Wendorf and Schild's interpretation, is located above the silt and sand deposits associated with maximum aggradation and dune sedimentation in the area. The surface concentrations are not dated, but on the basis of stratigraphic correlations and lithic comparisons, a date of around 16,500-14,500 cal BP was suggested for the Afian (Schild \& Wendorf 2010). However, Vermeersch and Van Neer (2015: 163) propose that instead of Nile river levels, the stratigraphy and topography around Esna might be better interpreted as Nile lake levels, similar to the one described for Makhadma (Vermeersch \& Van Neer 2015; and see above). The abundant lithic remains suggest repeated or long-term (or both) occupation(s). Close and colleagues (Close et al. 1979) made an extensive stylistic and typological study of these assemblages, while one locality, E71K18C, was recently studied from a technological point of view by one of us (Leplongeon 2017). The production was oriented towards making wide and small elongated blanks, following a planimetric 
conception of debitage, mainly relying on the principle of recurrence. Striking platforms are usually faceted and flaking surfaces were not prepared. Blanks were transformed into diverse retouched tools, composed mainly of microlithic tools: proximal truncations, backed bladelets and geometrics (mostly trapezes), occasionally manufactured using the microburin technique.
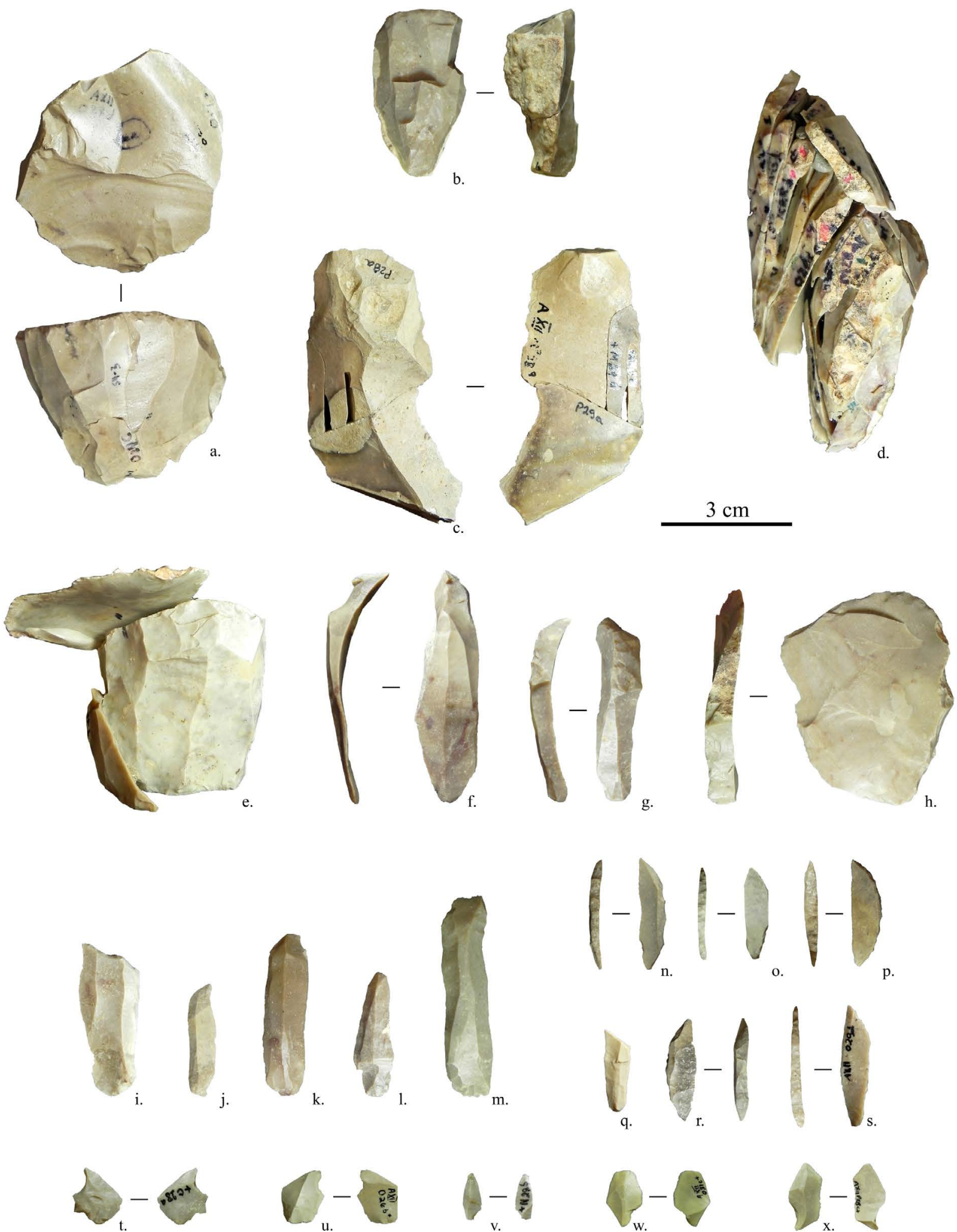

Figure 6. Azariq XII - lithic artefacts. a ,b, d, e = cores, c = refitted burin on a break on a flake, (f-h) core trimming elements, (i-m) elongated blanks, (n-s) arch-backed scalene bladelets, (t-x) microburins. 

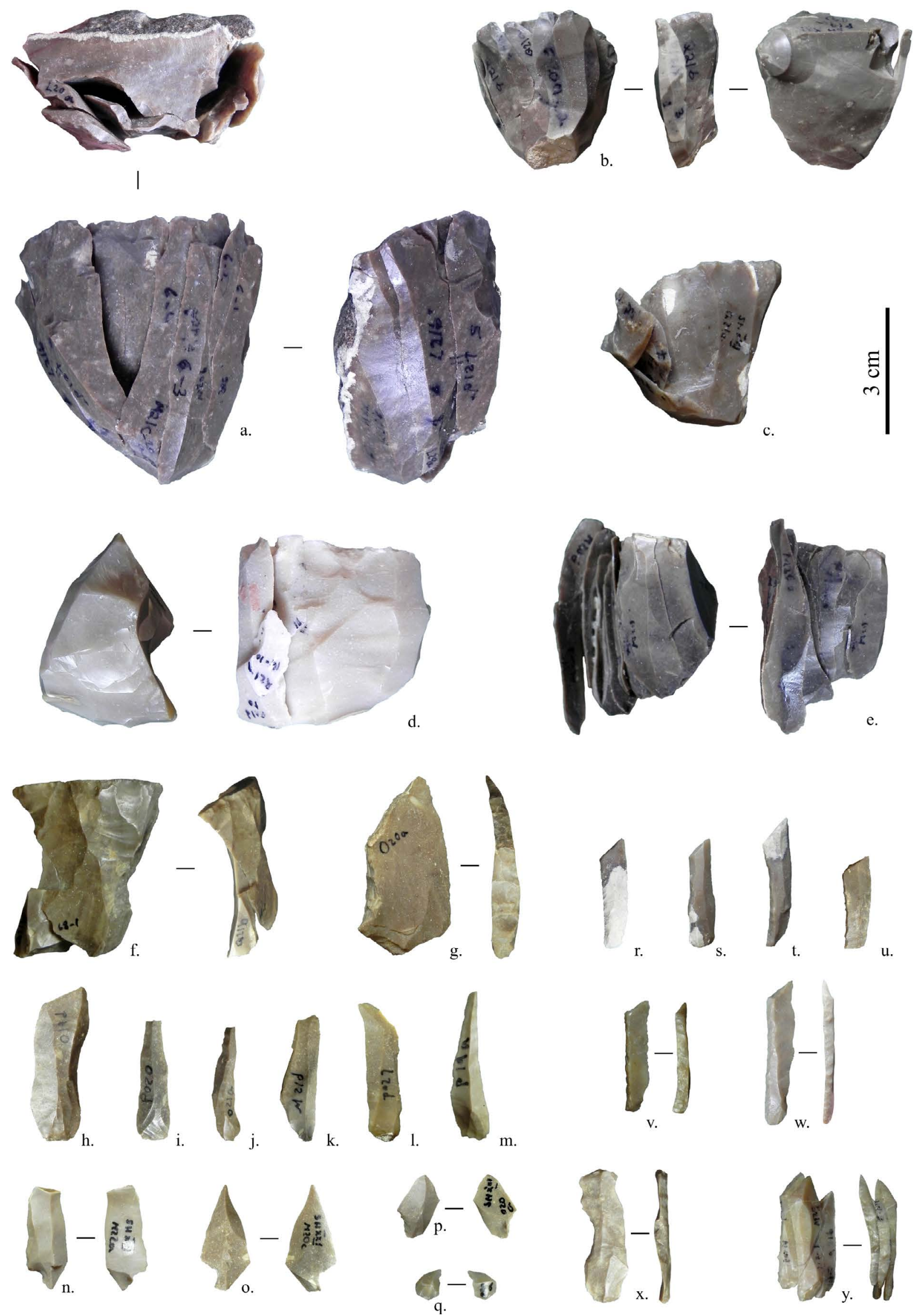

Figure 7. Shunera XXI - lithic artefacts. (a-e) cores, (f-g) core trimming elements, (h-m) elongated blanks, (n-q) microburins, $(\mathrm{r}-\mathrm{w})$ ramon points, $\mathrm{x}=$ unfinished microlith, $\mathrm{y}=$ refitted cluster of microliths. 
E71K20 is located about $5 \mathrm{~km}$ from E71K18. It is a surface site consisting of two lithic concentrations (areas A and B). Based on the general characteristics of the lithic assemblages, it was attributed to the Silsilian industry (Wendorf \& Schild 1976; Phillips \& Butzer 1973; Smith 1966). Its material was recently published by one of us (Leplongeon 2017). Blank production was oriented towards making short elongated products, frequently using a volumetric conception of debitage. Contrary to E71K18C, striking platforms were simply prepared and the convexities of the flaking surface were maintained through the removal of numerous core trimming elements. Blanks were transformed into both microlithic and macrolithic retouched tools, including distal truncations, but lack the microlithic geometric component of E71K18C.

These industries are thought to be broadly contemporaneous with the Early and Middle Epipalaeolithic of the Negev, although the absence of dates directly associated with the occupations at E71K18 and E71K20, as well as the different models existing for the Nile during the LGM, make their stratigraphic and chronological contexts debatable (Close et al. 1979; Wendorf \& Schild 1976; Schild \& Wendorf 2010; and see discussions in Leplongeon 2017). However, both sites are located among the northernmost ones known along the Nile Valley, with their assemblages available for study. Both are blade(let) industries with microliths and the use of the microburin technique. They can thus be used for preliminary comparative analyses to test hypotheses of terminal Pleistocene contacts between the southern Levant and the Nile Valley.

\section{Methods}

\subsection{Lithic analysis and sampling method}

Methods used for the analysis rely on the chaîne opératoire approach, combined with an attribute analysis in order to best characterise each assemblage (qualitatively and quantitatively) for detailed comparative analyses. Previous studies demonstrated that all assemblages are oriented towards elongated blank production and that the main chaîne opératoires are dedicated to microlith production. Analysis is based on representative 'stratified sampling' (Table 3). Each assemblage was divided into 'subpopulations', i.e., broad categories (cores, core trimming elements (CTE), elongated blanks, retouched tools) and complete pieces from each of these categories were randomly sampled. It did not include refitted items. One main bias relates to the use of stratified sampling; however, the aim herein is not to compare proportions between categories but rather characteristics within each category. Stratified sampling is therefore an advantage rather than an impediment.

Table 3. Studied samples. Abbreviations: CTE - core trimming element.

\begin{tabular}{llllll}
\hline Site & Cores & Elongated and CTE's & Microburins & Retouched tools & Total \\
\hline Azariq XIII & 12 & 248 & 0 & 210 & 470 \\
Azariq IV & 8 & 184 & 0 & 109 & 301 \\
Hamifgash IV & 10 & 158 & 92 & 118 & 378 \\
Azariq XVI & 12 & 167 & 0 & 220 & 399 \\
Azariq XII & 19 & 174 & 83 & 116 & 392 \\
Shunera XXI & 6 & 133 & 107 & 107 & 353 \\
\hline
\end{tabular}

Elongated blanks are here defined as any blank with a length:width ratio of at least 2. Kmeans cluster analysis (Pargeter \& Pargeter 2016; Pargeter \& Redondo 2016) was used to distinguish large elongated blanks (or blades) from small elongated blanks (bladelets) in the assemblages. Inter-assemblage differences were quantified using non-parametric statistical 
tests, enabling analysis of non-normally distributed variables, such as Kruskal-Wallis test and post-hoc Dunn's test (Dunn 1964; Carlson 2017: 182). All statistical tests have been performed with $\mathrm{R}$, R Studio and the graphs have been generated using the ggplot2 package ( $\mathrm{R}$ Core Team 2016; RStudio Team 2015; Wickham 2009). A list and description of the variables recorded as well as the full database are presented in Supplementary Information (SI) 1 and 2. Table 3 shows the sample studied.

\subsection{Limitations of the study}

This paper attempts to characterise lithic variability, between $25 \mathrm{ka}$ and $15 \mathrm{ka}$, at the intraregional scale (within the western Negev) and at the inter-regional scale (between the Negev and Upper Egypt), based on study of six assemblages from the Negev and two from the Nile Valley.

Interpretation of the results must take into account several caveats: firstly, the sample includes only one site per socio-cultural entity. It assumes that each assemblage is representative of that entity and that intra-entity variability is not apparent in the sample, although considerable intra-entity variability has been demonstrated by previous studies (Goring-Morris 1987; Marder 2002). Secondly, this analysis occurred after a major refitting programme. The artefacts analysed here are therefore, for the major part, not those that were refitted. The third relates to the different contexts of the Negev and the Nile Valley sites. In addition to the distance between the two group of sites ( $>800 \mathrm{~km}$ via the Nile Delta), while the Negev sites probably represent short-term occupations, the Nile Valley sites are probably the result of multiple occupations, which may have occurred over longer periods of time. Poor chronological control of the sites from the Nile Valley prevents any discussion of the direction of potential movements of technical diffusion (out-of or back-into Africa). Additionally, the type of material analysed (lithics) renders it difficult to distinguish between transmission of a behavioural trait with or without actual population movements, i.e., with or without gene flow (e.g., Premo \& Tostevin 2016; Tostevin 2012). Results of the comparative analysis therefore enables us to discuss only hypothetical contacts (direct or indirect), or convergence between the two areas. In addition, this period is characterised by the development of style in lithic assemblages, at least in the EP of the Levant (Goring-Morris \& Belfer-Cohen 1997), which has been interpreted to reflect increased territoriality. In this context, it is thus expected that we find marked typological differences between geographical areas. Hypothetical evidence for contacts would thus mainly consist of technological similarities.

While these limitations need to be clearly stated, in the absence of other data (sites closer to each other and more precise chronological resolution), we believe that the present comparative analysis may be considered as a first systematic attempt to investigate possible transmissions in technical behaviours between the Nile Valley and the southern Levant during the terminal Pleistocene.

\section{Results}

\subsection{General characteristics of cores, core trimming elements and elongated blanks}

In all sites except Azariq XVI (Geometric Kebaran), most cores have a single platform with unidirectional debitage (Table 4). Cores from all sites display plain striking platforms (usually with abrasion of removal surfaces). In terms of volumetric conception, Azariq XIII (Masraqan) distinguishes itself from the other sites by the dominance of convergent N-fronted cores. Although they are present also at Azariq IV (Kebaran) and Hamifgash IV (Nizzanan), both Early Epipalaeolithic sites, they are less numerous. 
Table 4. Characteristics of platform cores from sites studied.

\begin{tabular}{|c|c|c|c|c|c|c|c|}
\hline \multirow{2}{*}{\multicolumn{2}{|c|}{ Single }} & \multirow{2}{*}{\multicolumn{2}{|c|}{\begin{tabular}{|c|} 
Two opposed \\
Unidirectional \\
Bidirectional \\
successive
\end{tabular}}} & \multirow[t]{2}{*}{$\begin{array}{l}\text { Two non- } \\
\text { opposed }\end{array}$} & \multicolumn{2}{|c|}{ Multiple } & \multirow[t]{2}{*}{ Total } \\
\hline & & & & & $\begin{array}{l}2 \text { knapping } \\
\text { surfaces }\end{array}$ & $\begin{array}{l}3 \text { knapping } \\
\text { surfaces }\end{array}$ & \\
\hline$A z X I I I$ & 8 & & & 1 & & & 9 \\
\hline Cobble & 2 & & & & & & 2 \\
\hline Flake or split & 6 & & & 1 & & & 7 \\
\hline Az IV & 6 & 1 & & 2 & & & 9 \\
\hline Cobble & 4 & 1 & & 2 & & & 7 \\
\hline Flakeor split & 2 & & & & & & 2 \\
\hline Ham IV & 8 & & 1 & & & 1 & 10 \\
\hline Cobble & 6 & & 1 & & & 1 & 8 \\
\hline Flakeor split & 2 & & & & & & 2 \\
\hline$A z X V I$ & 6 & 4 & 1 & & & & 11 \\
\hline Cobble & 5 & 2 & 1 & & & & 8 \\
\hline Flakeor split & 1 & 2 & & & & & 3 \\
\hline$A z X I I$ & 7 & 2 & 3 & 5 & & 1 & 18 \\
\hline Cobble & 7 & 2 & 3 & 5 & & 1 & 18 \\
\hline Sh XXI & 15 & 2 & & 3 & 1 & & 21 \\
\hline Cobble & 9 & 2 & & 2 & 1 & & 14 \\
\hline Flakeor split & 6 & & & 1 & & & 7 \\
\hline Total & 50 & 9 & 5 & 11 & 1 & 2 & 78 \\
\hline
\end{tabular}

Despite these differences, there is no significant difference in the dimensions of the cores (Table 5).

Table 5. Metrics for the cores of the sites studied (in mm). Abbreviations: sd - standard deviation.

\begin{tabular}{lccccc}
\hline Site & count & mean length (L) & sd (L) & mean width (W) & sd (W) \\
\hline Azariq XIII & 5 & 37.8 & 13.2 & 26.0 & 5.4 \\
Azariq IV & 9 & 44.1 & 7.3 & 35.3 & 15.6 \\
Hamifgash IV & 10 & 42.1 & 12.6 & 35.0 & 4.8 \\
Azariq XVI & 10 & 45.2 & 9.2 & 41.1 & 8.9 \\
Azariq XII & 16 & 41.1 & 9.5 & 35.0 & 6.7 \\
Shunera XXI & 21 & 36.6 & 6.8 & 33.7 & 7.9 \\
\hline
\end{tabular}

Core trimming elements indicate platform management through the removal of core tablets or platform blades. Convexities of the debitage volume are mainly maintained by the removal of overpassed blanks or crested products rather than by side-core products. Overpassed products tend to be more numerous in assemblages with a higher frequency of two or more platform cores, i.e., Middle Epipalaeolithic assemblages of Azariq XII, Azariq XVI and Shunera XXI.

Results of the cluster analysis to distinguish blades from bladelets are consistent with previous studies and core dimensions: most assemblages were mainly oriented towards the production of bladelets.

The use of two distinct raw material categories is only present at Shunera XXI - flint $(\mathrm{n}=100)$ and chalcedony $(\mathrm{n}=10)$. Although elongated blanks on chalcedony appear slightly smaller (mean $=29.4 \mathrm{~mm}$, sd=3.5) and narrower (mean=9.5 mm, sd $=2.8$ ), compared to elongated blanks on flint (respectively mean length $=32.7 \mathrm{~mm}$, $\mathrm{sd}=8.9$; mean width $=11.6$, $\mathrm{sd}$ 
$=4.3$ ), the differences are not significant and elongated blanks from both raw materials were lumped together.

Inter-site comparisons (see Figure 8 and Table 6) demonstrate that Azariq XIII (Masraqan) distinguishes itself from all other assemblages with much narrower elongate blanks (mean width $=7.9 \mathrm{~mm}$, sd=2.6; mean length: width ratio $=4.3$, $\mathrm{sd}=1.2$; and mean width ranging from 11.5 to $13.5 \mathrm{~mm}$, and mean length:width ratio ranging from 3 to 3.2). Elongated blanks from Shunera XXI also stand apart from the other sites by being significantly smaller than at other Middle Epipalaeolithic sites (Azariq XVI and Azariq XII), and thinner than all other EP sites. When only the smaller elongated blanks are considered, the metric differences between Azariq XIII and the other sites are still significant, while it is more nuanced for Shunera XXI (see Table 7).

Table 6 - Main statistics for elongated blanks. Abbreviations: L - Length, W - Width, T - Thickness, sd standard deviation.

\begin{tabular}{|c|c|c|c|c|c|c|c|c|c|c|}
\hline \multirow[b]{2}{*}{ Dimensions (mm) } & \multicolumn{5}{|c|}{ Elongated - all } & \multicolumn{5}{|c|}{ Bladelets only } \\
\hline & $\mathbf{L}$ & $\mathbf{w}$ & $\mathbf{T}$ & L/W & W/T & $\mathbf{L}$ & $\mathbf{w}$ & $\mathbf{T}$ & L/W & $W / T$ \\
\hline Azariq XIII & \multicolumn{5}{|c|}{$\mathrm{N}=84$} & \multicolumn{5}{|c|}{$\mathrm{N}=68$} \\
\hline mean & 32.3 & 7.9 & 2.7 & 4.3 & 3.1 & 29.2 & 7.3 & 2.5 & 4.2 & 3.1 \\
\hline$s d$ & 8.3 & 2.6 & 0.9 & 1.2 & 0.9 & 4.7 & 1.7 & 0.7 & 1.2 & 1 \\
\hline Min & 17.8 & 3.6 & 1.2 & 2.2 & 1.3 & 17.8 & 3.6 & 1.2 & 2.2 & 1.3 \\
\hline Max & 67.7 & 18.6 & 6.8 & 8.1 & 6.1 & 37.1 & 12.4 & 4.5 & 8.1 & 6.1 \\
\hline Azariq IV & \multicolumn{5}{|c|}{$\mathrm{N}=80$} & \multicolumn{5}{|c|}{$\mathrm{N}=63$} \\
\hline mean & 36.6 & 12.1 & 4.7 & 3.1 & 2.9 & 31.2 & 10.3 & 3.8 & 3.1 & 3 \\
\hline$s d$ & 13.1 & 5 & 2.7 & 0.7 & 0.9 & 6.8 & 2.6 & 1.5 & 0.7 & 0.9 \\
\hline Min & 16.3 & 5.5 & 1.2 & 2.1 & 1 & 16.3 & 5.5 & 1.2 & 2.1 & 1.6 \\
\hline Max & 82.3 & 32.4 & 16.9 & 5.8 & 4.9 & 43.4 & 15.9 & 7.6 & 5.8 & 4.9 \\
\hline Hamifgash IV & \multicolumn{5}{|c|}{$\mathrm{N}=60$} & \multicolumn{5}{|c|}{$\mathrm{N}=28$} \\
\hline mean & 37.2 & 12.4 & 5.2 & 3.2 & 2.9 & 27.1 & 9.6 & 3.5 & 2.9 & 3.2 \\
\hline$s d$ & 11.3 & 4.5 & 3.2 & 1.1 & 1.2 & 5.2 & 2.4 & 1.7 & 0.8 & 1.2 \\
\hline Min & 17.4 & 4.9 & 1.2 & 2 & 0.7 & 17.4 & 4.9 & 1.2 & 2 & 1 \\
\hline Max & 67 & 23.2 & 18 & 6.4 & 5.3 & 33.9 & 15.2 & 8.2 & 5.1 & 5.2 \\
\hline Azariq XVI & \multicolumn{5}{|c|}{$\mathrm{N}=153$} & \multicolumn{5}{|c|}{$\mathrm{N}=98$} \\
\hline mean & 39.4 & 13.5 & 4.2 & 3.1 & 3.7 & 32.1 & 11 & 3.5 & 3.1 & 3.7 \\
\hline$s d$ & 12 & 4.9 & 2.3 & 0.8 & 1.3 & 6 & 3.2 & 1.9 & 0.8 & 1.3 \\
\hline Min & 18.4 & 5.1 & 1 & 2 & 0.7 & 18.4 & 5.1 & 1 & 2 & 0.7 \\
\hline Max & 73.1 & 28.6 & 10.7 & 6.9 & 7.7 & 43 & 18.2 & 10.4 & 6.9 & 7.7 \\
\hline Azariq XII & \multicolumn{5}{|c|}{$N=139$} & \multicolumn{5}{|c|}{$\mathrm{N}=72$} \\
\hline mean & 40.1 & 13.3 & 4 & 3.1 & 3.8 & 31.4 & 10.4 & 2.8 & 3.1 & 4.1 \\
\hline sd & 11 & 4.2 & 2 & 0.6 & 1.3 & 4.7 & 2.4 & 1.1 & 0.5 & 1.3 \\
\hline Min & 21.4 & 5.8 & 1.2 & 2.1 & 1.4 & 21.4 & 5.8 & 1.2 & 2.1 & 2.1 \\
\hline Max & 77 & 22.6 & 13.6 & 6.5 & 9.1 & 40 & 16.9 & 6.4 & 4.5 & 9.1 \\
\hline Shunera XXI & \multicolumn{5}{|c|}{$\mathrm{N}=120$} & \multicolumn{5}{|c|}{$\mathrm{N}=96$} \\
\hline mean & 32.4 & 11.4 & 3.3 & 3 & 3.9 & 29 & 10 & 2.7 & 3.1 & 4 \\
\hline$s d$ & 8.5 & 4.1 & 2 & 0.7 & 1.2 & 4.4 & 2.8 & 1.3 & 0.7 & 1.2 \\
\hline Min & 20.7 & 5 & 1.3 & 2 & 1.2 & 20.7 & 5 & 1.3 & 2 & 1.7 \\
\hline $\operatorname{Max}$ & 70.6 & 24 & 12.5 & 5.2 & 7.1 & 37.7 & 16.5 & 8 & 5.2 & 7.1 \\
\hline
\end{tabular}




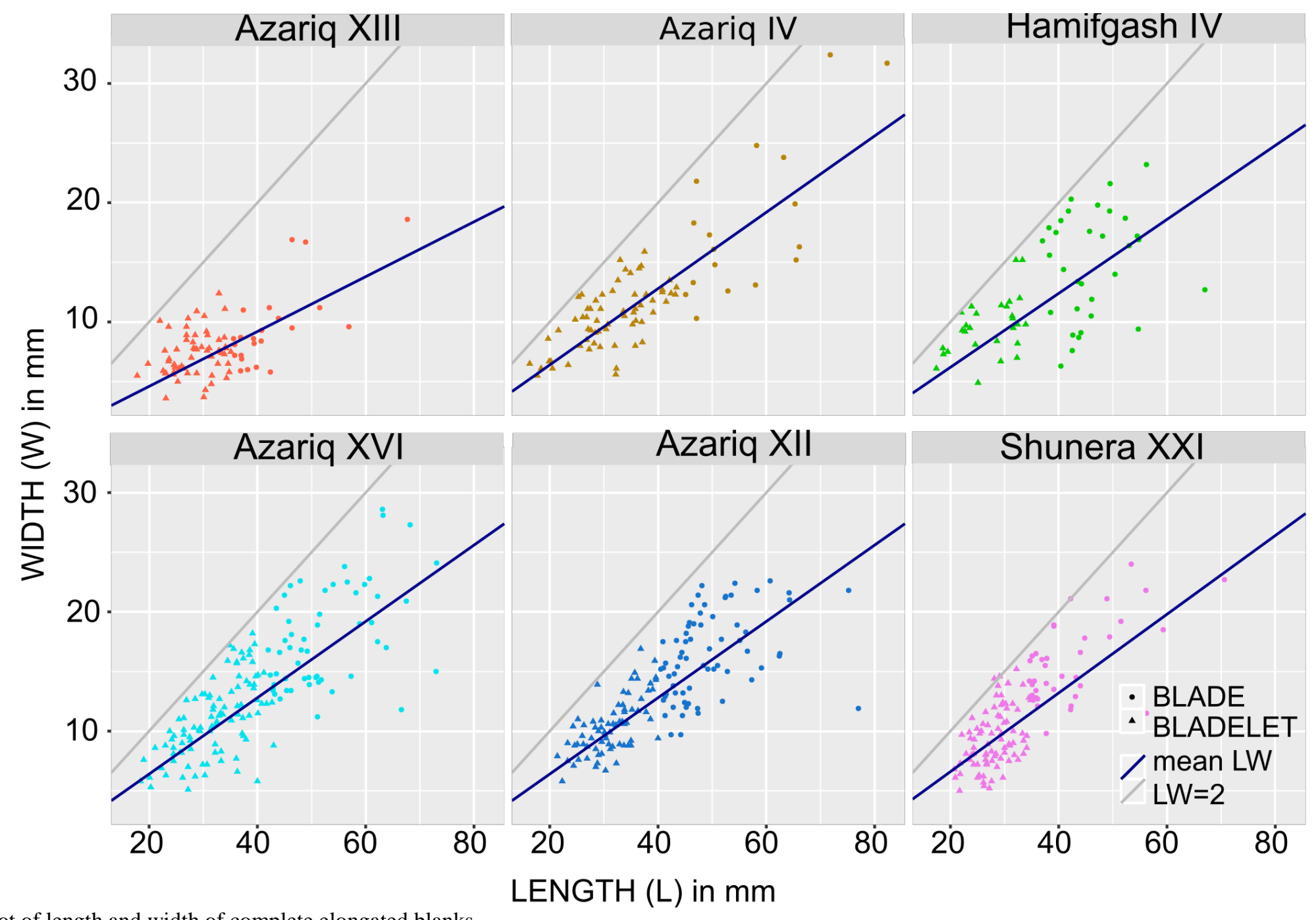

Figure 8. Biplot of length and width of complete elongated blanks. 
Table 7. Results of Kruskal-Wallis tests and post-hoc Dunn's test (Carlson 2017: 182; Dunn 1964) for the comparisons of dimensions of elongated blanks between sites. Abbreviations: ** p-value <.01; Az - Azariq; Shun - Shunera; Ham - Hamifgash.

\begin{tabular}{|c|c|c|c|c|c|c|}
\hline & \multicolumn{3}{|c|}{ Elongated (all) } & \multicolumn{3}{|c|}{ Bladelets only } \\
\hline & $\begin{array}{l}\text { K-W Chi- } \\
\text { square }\end{array}$ & $\begin{array}{c}\mathrm{P}- \\
\text { value }\end{array}$ & Dunn's test & $\begin{array}{l}\text { K-W Chi- } \\
\text { square }\end{array}$ & $\begin{array}{c}\text { P- } \\
\text { value }\end{array}$ & Dunn's test \\
\hline Length (L) & 59.2 & $* *$ & $\begin{array}{l}\text { Significant only } \\
\text { between: AzXIII \& AzXII, } \\
\text { ShunXXI, AzXVI \& AzXII, } \\
\text { ShunXXI \& AzXVI }\end{array}$ & 44.7 & $* *$ & $\begin{array}{l}\text { Significant only } \\
\text { between: AzXVI \& all } \\
\text { but AzXII; AzXII \& all but } \\
\text { AzXVI; AzIV \& ShunXXI }\end{array}$ \\
\hline Width (W) & 118.6 & $* *$ & $\begin{array}{l}\text { Significant only } \\
\text { between: AzXIII and all } \\
\text { others, ShunXXI \& AzXII, } \\
\text { AzXVI }\end{array}$ & 74.6 & $* *$ & $\begin{array}{l}\text { Significant only } \\
\text { between: AzXIII \& all; Az } \\
\text { XVI \& ShunXXI }\end{array}$ \\
\hline Thickness (T) & 69.7 & $* *$ & $\begin{array}{l}\text { Significant only } \\
\text { between: AzXIII \& all but } \\
\text { ShunXXI; ShunXXI \& all } \\
\text { but AzXIII }\end{array}$ & 53.9 & $* *$ & $\begin{array}{l}\text { Significant only } \\
\text { between: AzIV \& AzXII, } \\
\text { AzXIII, ShunXXI; AzXVI \& } \\
\text { AzXIII, ShunXXI; HamIV } \\
\text { \& ShunXXI }\end{array}$ \\
\hline L/W & 91.9 & $* *$ & $\begin{array}{l}\text { Significant only } \\
\text { between: AzXIII \& all } \\
\text { others }\end{array}$ & 56.5 & $* *$ & $\begin{array}{l}\text { Significant only } \\
\text { between: AzXIII \& all } \\
\text { others }\end{array}$ \\
\hline $\mathrm{W} / \mathrm{T}$ & 59.86 & $* *$ & $\begin{array}{l}\text { Significant for most of } \\
\text { all, except between: AzIV } \\
\text { \& AzXIII, HamIV; AzXII \& } \\
\text { AzXVI, ShunXXI; AzXIII \& } \\
\text { HamIV, AzXVI \& ShunXXI }\end{array}$ & 48.9 & $* *$ & $\begin{array}{l}\text { Significant only between } \\
\text { AzXIII \& ShunXXI, AzXII; } \\
\text { Az IV \& AzXII, AzXVI, } \\
\text { ShunXXI }\end{array}$ \\
\hline
\end{tabular}

\subsection{Direction of core reduction, platform management and dorsal surface convexity}

Complete and almost complete elongated blanks have a mean number of scar removals ranging from 4 to 5 at all sites (Table 8). They mainly display a unidirectional dorsal scar pattern. However, some significant differences are observed between the sites. In particular, Azariq XIII, Hamifgash IV and Shunera XXI have the highest frequencies of unidirectional dorsal scar patterns (72-80\% against $65-70 \%$ for the other assemblages), while Azariq XVI shows the highest frequency of bidirectional scars (14\% against $<12 \%$ at the other sites) (Figure 9). When investigating the link between the scar patterns and dimensions of elongated blanks, there is a significant difference only at Shunera XXI between elongated blanks with unidirectional and bidirectional scar patterns, suggesting that, although few, larger bidirectional blanks $(\mathrm{N}=12$, mean $=37.4 \mathrm{~mm}$, $\mathrm{sd}=8.1)$ were produced in earlier stages of the reduction sequences than unidirectional blanks $(\mathrm{N}=93$, mean $=31.3 \mathrm{~mm}$, sd $=7.9)$. This would explain why most of the cores are single platform cores.

Characteristics of the proximal parts of all elongated blanks display mainly plain platforms at Hamifgash IV and Azariq IV (68-72\%) and linear or punctiform types at the other sites (56-70\%) (Table 9). In addition, while abrasion of the platform seems to be systematic at Azariq XIII, Azariq XII and Shunera XXI (>75\%), it is less frequent at Hamifgash IV, Azariq IV and Azariq XVI (20-59\%). In all assemblages except Azariq IV, bulbs are mainly not to slightly salient. Experiments have demonstrated that there is no direct correlation between one attribute (such as the salience of the bulb or the presence / absence of a lip) and a specific percussion technique. However, the quantification of a combination of attributes may help to indicate predominant use of a specific technique (Tixier, 1982; Pèlegrin 2000). Overall, the characteristics of the proximal parts of elongated blanks may imply the use of a soft stone hammer at Azariq XIII, while a harder hammerstone could have been used 
at Azariq IV and Hamifgash IV. Although patterns are less clear for the other sites, a soft stone hammer also may be suggested (and see Marder 2002, chapter V). Detailed experiments would be necessary to confirm this.

Table 8. Number of dorsal scars and types of scar pattern of the elongated blanks. In bold: values with the highest (positive or negative) residuals of the Chi2 test $(<1.2$ or $>1.2)$. Az - Azariq; Shun - Shunera; Ham Hamifgash.

\begin{tabular}{lccccccc} 
& & $\begin{array}{c}\text { Az XIII } \\
(\mathbf{n}=\mathbf{1 4 0})\end{array}$ & $\begin{array}{c}\text { Az IV } \\
(\mathbf{n}=\mathbf{1 0 9})\end{array}$ & $\begin{array}{c}\text { Ham IV } \\
(\mathbf{n}=\mathbf{9 6})\end{array}$ & $\begin{array}{c}\text { Az XVI } \\
(\mathbf{n}=\mathbf{1 5 3})\end{array}$ & $\begin{array}{c}\text { Az XII } \\
(\mathbf{n}=\mathbf{1 4 1})\end{array}$ & $\begin{array}{c}\text { Shun XXI } \\
(\mathbf{n}=\mathbf{1 2 0})\end{array}$ \\
\hline nb dorsal scars & mean & 4.8 & 5.1 & 3.9 & 5 & 4.5 & 4.7 \\
& $\mathrm{~s}$ & 1.9 & 2.1 & 1.6 & 1.9 & 1.6 & 1.7 \\
\hline Bidirectional & $\mathrm{N}$ & 4 & 13 & 6 & 21 & 16 & 12 \\
& $\%$ & $2.90 \%$ & $11.90 \%$ & $6.30 \%$ & $13.70 \%$ & $11.30 \%$ & $10.00 \%$ \\
\hline Centripetal & $\mathrm{N}$ & 0 & 2 & 0 & 4 & 5 & 1 \\
& $\%$ & $0.00 \%$ & $1.80 \%$ & $0.00 \%$ & $2.60 \%$ & $3.50 \%$ & $0.80 \%$ \\
\hline Unidirectional & $\mathrm{N}$ & 111 & 71 & 69 & 101 & 100 & 93 \\
& $\%$ & $80.40 \%$ & $65.10 \%$ & $71.90 \%$ & $66.00 \%$ & $70.90 \%$ & $77.50 \%$ \\
\hline Unidirectional \& lateral & $\mathrm{N}$ & 22 & 19 & 20 & 24 & 20 & 14 \\
& $\%$ & $15.90 \%$ & $17.40 \%$ & $20.80 \%$ & $15.70 \%$ & $14.00 \%$ & $11.70 \%$ \\
\hline One direction & $\mathrm{N}$ & 1 & 4 & 1 & 3 & 0 & 0 \\
& $\%$ & $0.70 \%$ & $3.70 \%$ & $1.00 \%$ & $2.00 \%$ & $0.00 \%$ & $0.00 \%$ \\
\hline
\end{tabular}

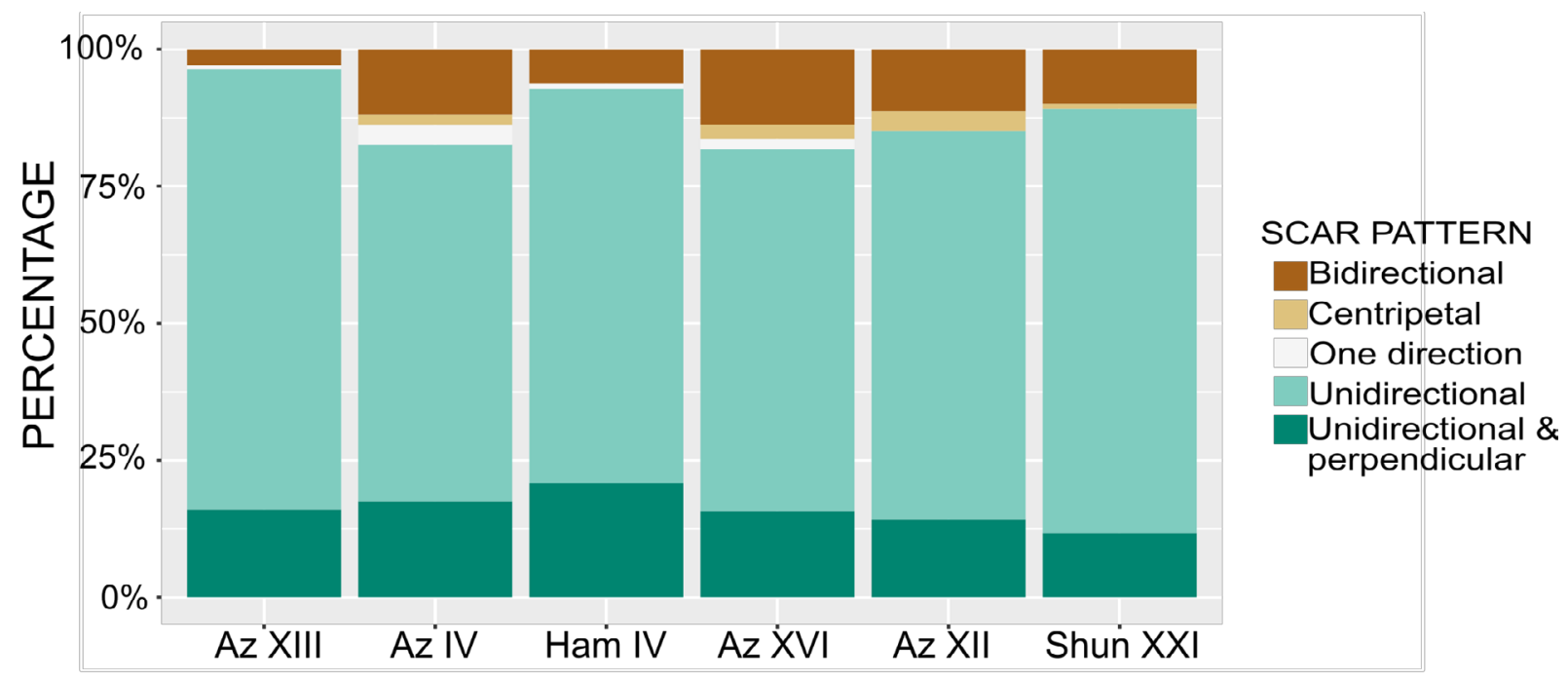

SITES

Figure 9. Relative percentages of scar patterns. Az - Azariq; Shun - Shunera; Ham - Hamifgash.

The general morphological characteristics of elongated blanks display high percentages of distally convergent blanks in all sites (33-46\%), especially marked at Shunera XXI (46\%). Azariq XIII has the highest frequency of regular parallel blanks (23\%, against $5-14 \%$ at the other sites). Curved to very curved blank profiles dominate at all sites, although there is a higher percentage of curved blanks at Azariq XIII, as opposed to flat blanks at Hamifgash IV and Azariq IV. Distal terminations are usually feathered, particularly at Azariq XIII ( 80\%), although higher percentages of hinged blanks are observed at Hamifgash IV, Azariq IV and Azariq XVI (8-12\%), which may indicate the at least occasional use of a hard hammerstone (Table 10). 
Table 9. Main characteristics of the proximal parts of elongated blanks. In bold: values with the highest residuals of the Chi2 test. Az - Azariq; Shun - Shunera; Ham Hamifgash.

\begin{tabular}{|c|c|c|c|c|c|c|c|c|c|c|c|c|c|}
\hline & & \multicolumn{2}{|c|}{ Az XIII } & \multicolumn{2}{|c|}{ Az IV } & \multicolumn{2}{|c|}{ Ham IV } & \multicolumn{2}{|c|}{ Az XVI } & \multicolumn{2}{|c|}{ Az XII } & \multicolumn{2}{|c|}{ Shun XXI } \\
\hline Platform types & & \multicolumn{2}{|c|}{$N=128$} & \multicolumn{2}{|c|}{$\mathrm{N}=93$} & \multicolumn{2}{|c|}{$\mathbf{N}=80$} & \multicolumn{2}{|c|}{$N=134$} & \multicolumn{2}{|c|}{$\mathrm{N}=128$} & \multicolumn{2}{|c|}{$\mathrm{N}=115$} \\
\hline plain & & 38 & $29.7 \%$ & 67 & $72.0 \%$ & 54 & $67.5 \%$ & 59 & $44.0 \%$ & 37 & $28.9 \%$ & 45 & $39.1 \%$ \\
\hline faceted or dihedral & & 0 & $0.0 \%$ & 4 & $4.3 \%$ & 0 & $0.0 \%$ & 0 & $0.0 \%$ & 1 & $0.8 \%$ & 0 & $0.0 \%$ \\
\hline linear or punctifom & & 89 & $69.5 \%$ & 22 & $23.7 \%$ & 23 & $28.8 \%$ & 75 & $56.0 \%$ & 90 & $70.3 \%$ & 68 & $59.1 \%$ \\
\hline cortical & & 1 & $0.8 \%$ & 0 & $0.0 \%$ & 3 & $3.7 \%$ & 0 & $0.0 \%$ & 0 & $0.0 \%$ & 2 & $1.7 \%$ \\
\hline Abrasion (presence of) & & 105 & $82.0 \%$ & 39 & $41.9 \%$ & 17 & $21.3 \%$ & 80 & $59.7 \%$ & 96 & $75.0 \%$ & 94 & $81.7 \%$ \\
\hline Platform Measurements (mm) & & \multicolumn{2}{|c|}{$\mathrm{N}=38$} & \multicolumn{2}{|c|}{$\mathrm{N}=66$} & \multicolumn{2}{|c|}{$\mathrm{N}=53$} & \multicolumn{2}{|c|}{$\mathrm{N}=59$} & \multicolumn{2}{|c|}{$\mathrm{N}=37$} & \multicolumn{2}{|c|}{$\mathrm{N}=45$} \\
\hline \multirow[t]{2}{*}{ platform breadth (ptf.B) } & mean & \multicolumn{2}{|c|}{3.2} & \multicolumn{2}{|c|}{4.6} & \multicolumn{2}{|c|}{5.1} & \multicolumn{2}{|c|}{5.5} & \multicolumn{2}{|c|}{5.7} & \multicolumn{2}{|c|}{5.1} \\
\hline & sd & \multicolumn{2}{|c|}{2.1} & \multicolumn{2}{|c|}{2.2} & \multicolumn{2}{|c|}{3.6} & \multicolumn{2}{|c|}{3} & \multicolumn{2}{|c|}{2.4} & \multicolumn{2}{|c|}{2} \\
\hline \multirow[t]{2}{*}{ platform thickness (ptf.T) } & mean & & .1 & & 1.7 & & .2 & & 1.9 & & 2.1 & & 1.7 \\
\hline & sd & & .7 & & 0.8 & & 2 & & 1.2 & & 1.4 & & 1 \\
\hline ptf.B / blank width & mean & & .4 & & 0.4 & & .4 & & .4 & & 0.4 & & 0.4 \\
\hline & sd & & .2 & & 0.1 & & .2 & & .2 & & 0.2 & & 0.2 \\
\hline ptf.T / blank thickness & mean & & .4 & & 0.4 & & .4 & & .5 & & 0.5 & & 0.5 \\
\hline & sd & & .2 & & 0.1 & & .2 & & .2 & & 0.3 & & 0.2 \\
\hline Types of bulb & & & 128 & & $=93$ & & $=80$ & & 134 & & $=128$ & & $=115$ \\
\hline not to slightly salient & & 73 & $57.0 \%$ & 25 & $26.9 \%$ & 34 & $42.5 \%$ & 69 & $51.5 \%$ & 56 & $43.8 \%$ & 57 & $50.0 \%$ \\
\hline salient & & 43 & $33.6 \%$ & 44 & $47.3 \%$ & 35 & $43.8 \%$ & 49 & $36.6 \%$ & 60 & $46.9 \%$ & 53 & $46.0 \%$ \\
\hline very salient & & 5 & $3.9 \%$ & 13 & $14.0 \%$ & 3 & $3.8 \%$ & 9 & $6.7 \%$ & 2 & $1.6 \%$ & 1 & $0.9 \%$ \\
\hline Deformed or broken & & 7 & $5.5 \%$ & 11 & $11.8 \%$ & 8 & $10.0 \%$ & 7 & $5.2 \%$ & 10 & $7.8 \%$ & 4 & $3.5 \%$ \\
\hline
\end{tabular}


Table 10. Comparisons between sites of main characteristics of elongated blanks. Significant differences are observed between the sites (Chi2 with simulate p-value). Highlighted values which have highest (positive or negative) residuals. Az - Azariq; Shun - Shunera; Ham - Hamifgash.

\begin{tabular}{|c|c|c|c|c|c|c|c|c|}
\hline & & & Az XIII & Az IV & Ham IV & $A z X V I$ & $A z X I I$ & Shun XXI \\
\hline \multirow{13}{*}{$\begin{array}{l}\text { Morphology } \\
\text { of } \\
\text { edges }\end{array}$} & Number & & $N=131$ & $\mathrm{~N}=107$ & $\mathrm{~N}=92$ & $N=151$ & $\mathrm{~N}=140$ & $\mathrm{~N}=115$ \\
\hline & Parallel & $\mathrm{N}$ & 30 & 15 & 13 & 17 & 9 & 6 \\
\hline & & $\%$ & $22.90 \%$ & $14.00 \%$ & $14.10 \%$ & $11.30 \%$ & $6.40 \%$ & $5.20 \%$ \\
\hline & Rounded & $\mathrm{N}$ & 24 & 28 & 30 & 57 & 47 & 30 \\
\hline & & $\%$ & $18.30 \%$ & $26.20 \%$ & $32.60 \%$ & $37.70 \%$ & $33.60 \%$ & $26.10 \%$ \\
\hline & Parallel-rounded & $\mathrm{N}$ & 24 & 20 & 8 & 19 & 26 & 17 \\
\hline & & $\%$ & $18.30 \%$ & $18.70 \%$ & $8.70 \%$ & $12.60 \%$ & $18.60 \%$ & $14.80 \%$ \\
\hline & Distally convergent & $\mathrm{N}$ & 49 & 38 & 33 & 50 & 52 & 53 \\
\hline & & $\%$ & $37.40 \%$ & $35.50 \%$ & $35.90 \%$ & $33.10 \%$ & $37.10 \%$ & $46.10 \%$ \\
\hline & Divergent & $\mathrm{N}$ & 0 & 4 & 6 & 7 & 4 & 5 \\
\hline & & $\%$ & $0.00 \%$ & $3.70 \%$ & $6.50 \%$ & $4.60 \%$ & $2.90 \%$ & $4.30 \%$ \\
\hline & Irregular & $\mathrm{N}$ & 4 & 2 & 2 & 1 & 2 & 4 \\
\hline & & $\%$ & $3.10 \%$ & $1.90 \%$ & $2.20 \%$ & $0.70 \%$ & $1.40 \%$ & $3.50 \%$ \\
\hline \multirow{11}{*}{$\begin{array}{l}\text { Curvature } \\
\text { of } \\
\text { longitudinal } \\
\text { Profile }\end{array}$} & Number & & $\mathrm{N}=138$ & $\mathrm{~N}=109$ & $\mathrm{~N}=96$ & $\mathrm{~N}=153$ & $\mathrm{~N}=141$ & $\mathrm{~N}=120$ \\
\hline & Flat & $\mathrm{N}$ & 9 & 24 & 17 & 16 & 11 & 15 \\
\hline & & $\%$ & $6.50 \%$ & $22.00 \%$ & $18.50 \%$ & $10.50 \%$ & $7.80 \%$ & $12.50 \%$ \\
\hline & Slightly curved & $N$ & 53 & 39 & 30 & 47 & 52 & 43 \\
\hline & & $\%$ & $38.40 \%$ & $35.80 \%$ & $31.30 \%$ & $30.70 \%$ & $36.90 \%$ & $35.80 \%$ \\
\hline & Curved & $\mathrm{N}$ & 59 & 25 & 30 & 54 & 53 & 41 \\
\hline & & $\%$ & $42.80 \%$ & $22.90 \%$ & $31.30 \%$ & $35.30 \%$ & $37.60 \%$ & $34.20 \%$ \\
\hline & Very curved & $\mathrm{N}$ & 9 & 14 & 12 & 25 & 17 & 12 \\
\hline & & $\%$ & $6.50 \%$ & $12.80 \%$ & $12.50 \%$ & $16.30 \%$ & $12.10 \%$ & $10.00 \%$ \\
\hline & $\mathrm{S}$ & $\mathrm{N}$ & 8 & 7 & 7 & 11 & 8 & 9 \\
\hline & & $\%$ & $5.80 \%$ & $6.40 \%$ & $7.30 \%$ & $7.20 \%$ & $5.70 \%$ & $7.50 \%$ \\
\hline \multirow{5}{*}{$\begin{array}{l}\text { Lateral } \\
\text { Profile }\end{array}$} & Number & & $\mathrm{N}=138$ & $N=109$ & $\mathrm{~N}=96$ & $N=153$ & $\mathrm{~N}=141$ & $\mathrm{~N}=120$ \\
\hline & Flat & $\mathrm{N}$ & 111 & 91 & 69 & 132 & 125 & 102 \\
\hline & & $\%$ & $80.40 \%$ & $83.50 \%$ & $71.90 \%$ & $86.30 \%$ & $88.70 \%$ & $85.00 \%$ \\
\hline & Slightly to twisted & $\mathrm{N}$ & 27 & 18 & 27 & 21 & 16 & 18 \\
\hline & & $\%$ & $19.60 \%$ & $16.50 \%$ & $28.10 \%$ & $13.70 \%$ & $11.30 \%$ & $15.00 \%$ \\
\hline \multirow{13}{*}{$\begin{array}{l}\text { Distal } \\
\text { Termination }\end{array}$} & Number & & $\mathrm{N}=142$ & $\mathrm{~N}=115$ & $N=106$ & $N=153$ & $N=141$ & $\mathrm{~N}=120$ \\
\hline & Feathered & $\mathrm{N}$ & 114 & 73 & 67 & 88 & 95 & 86 \\
\hline & & $\%$ & $80.30 \%$ & $63.50 \%$ & $63.20 \%$ & $57.50 \%$ & $67.40 \%$ & $71.70 \%$ \\
\hline & Hinged & $\mathrm{N}$ & 2 & 10 & 6 & 5 & 1 & 2 \\
\hline & & $\%$ & $1.40 \%$ & $8.70 \%$ & $5.70 \%$ & $3.30 \%$ & $0.70 \%$ & $1.70 \%$ \\
\hline & Overpassed & $\mathrm{N}$ & 6 & 11 & 9 & 19 & 16 & 10 \\
\hline & & $\%$ & $4.20 \%$ & $9.60 \%$ & $8.50 \%$ & $12.40 \%$ & $11.30 \%$ & $8.30 \%$ \\
\hline & Slightly hinged & $\mathrm{N}$ & 0 & 3 & 13 & 13 & 5 & 5 \\
\hline & & $\%$ & $0.00 \%$ & $2.60 \%$ & $12.20 \%$ & $8.50 \%$ & $3.50 \%$ & $4.20 \%$ \\
\hline & Slightly overpassed & $\mathrm{N}$ & 19 & 18 & 10 & 26 & 22 & 16 \\
\hline & & $\%$ & $13.40 \%$ & $15.70 \%$ & $9.40 \%$ & $17.00 \%$ & $15.60 \%$ & $13.30 \%$ \\
\hline & Step & $\mathrm{N}$ & 1 & 0 & 1 & 2 & 2 & 1 \\
\hline & & $\%$ & $0.70 \%$ & $0.00 \%$ & $0.90 \%$ & $1.30 \%$ & $1.40 \%$ & $0.80 \%$ \\
\hline
\end{tabular}




\subsection{Use of the microburin technique}

The assemblages may be divided into two groups according to the systematic use of the microburin technique (see Tables 1 and 11). It is habitual at Hamifgash IV, Azariq XII and Shunera XXI, with relatively high microburin indices (see Table 11).

Table 11. Number of microburins and microburin indices (After Goring-Morris 1987). Abbreviations: * Mostly Krukowski microburins. Imbt = Microburin index; Imbtr $=$ restricted microburin index (Henry 1974).

\begin{tabular}{llll}
\hline Site & Nb microburins & Imbt & Imbtr \\
\hline Azariq XIII & - & - & - \\
Azariq IV & 1 & - & - \\
Hamifgash IV & 275 & 48.6 & 57.7 \\
Azariq XVI & $46^{*}$ & 3.7 & 4.6 \\
Azariq XII & 358 & 21.2 & 26 \\
Shunera XXI & 604 & 35.1 & 62.2 \\
\hline
\end{tabular}

Proximal and distal microburins are almost equally represented at Hamifgash IV and Azariq XII, while mostly distal microburins are present at Shunera XXI (see Goring-Morris 1987). Proximal microburins are significantly longer at Hamifgash IV (mean length=18.4, $\mathrm{sd}=6.3$ ) than at the other sites (mean length between 12 and $13.4 \mathrm{~mm}$ ), while distal microburins, and in general all types of microburins are smaller at Azariq XII (mean length dist $=14.1 \mathrm{~mm}$, sd=2.9; compared to mean length between 17.3 and $18.8 \mathrm{~mm}$ ) than at the other sites (see Table 12).

Table 12. Main dimensions of microburins

\begin{tabular}{lcccccccc}
\hline & & \multicolumn{3}{c}{ length (L) - } & \multicolumn{2}{c}{ width (W) - } & \multicolumn{3}{c}{ Thickness (T) } \\
Site & Segment & count & mean & L - sd & mean & W - sd & - mean & T - sd \\
\hline Azariq XII & DIST & 33 & 14.05 & 2.92 & 7.7 & 2.32 & 2.5 & 0.8 \\
Hamifgash IV & DIST & 32 & 18.76 & 6.08 & 8.06 & 2.52 & 2.47 & 0.59 \\
Shunera XXI & DIST & 92 & 17.3 & 5.63 & 9.05 & 2.72 & 2.68 & 1.13 \\
Azariq XII & MES & 6 & 10.48 & 2.46 & 8.12 & 1.34 & 1.95 & 0.5 \\
Hamifgash IV & MES & 13 & 14.4 & 4.53 & 10.04 & 4.15 & 2.46 & 0.72 \\
Azariq XII & PROX & 44 & 13.36 & 3.94 & 9.11 & 2.22 & 2.71 & 0.52 \\
Hamifgash IV & PROX & 47 & 18.36 & 6.34 & 9.84 & 2.37 & 2.94 & 0.73 \\
Shunera XXI & PROX & 15 & 11.97 & 4.05 & 8.75 & 3.09 & 2.62 & 0.61 \\
\hline
\end{tabular}

In comparing the dimensions of microburins with those of elongated blanks, microburins are significantly narrower and thinner in all cases but one (p-value $<.01$, Wilcoxon MannWhitney test, Figure 10), indicating that the elongated blanks chosen for manufacture into retouched tools were in fact smaller than those left 'intact'.

As expected, microburins are much wider than retouched bladelets, while relative thickness does not show any specific pattern (Figure 11).

These results seem to indicate that the blanks selected to be retouched may not have the same characteristics as the complete elongated blanks found in the assemblages, so that interpretation of their characteristics must take that into account (Goring-Morris 1987: 372). 


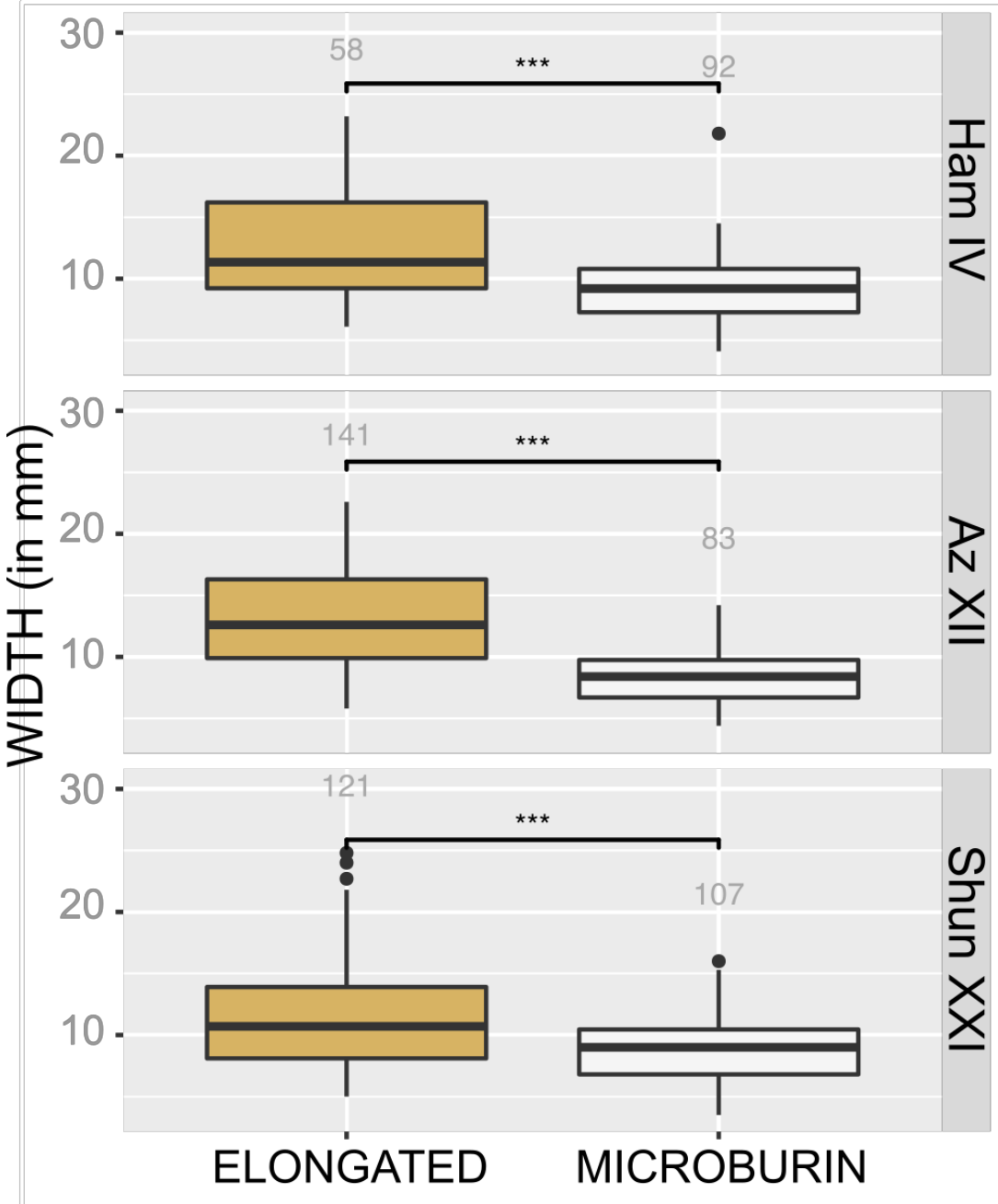

TYPE OF BLANK

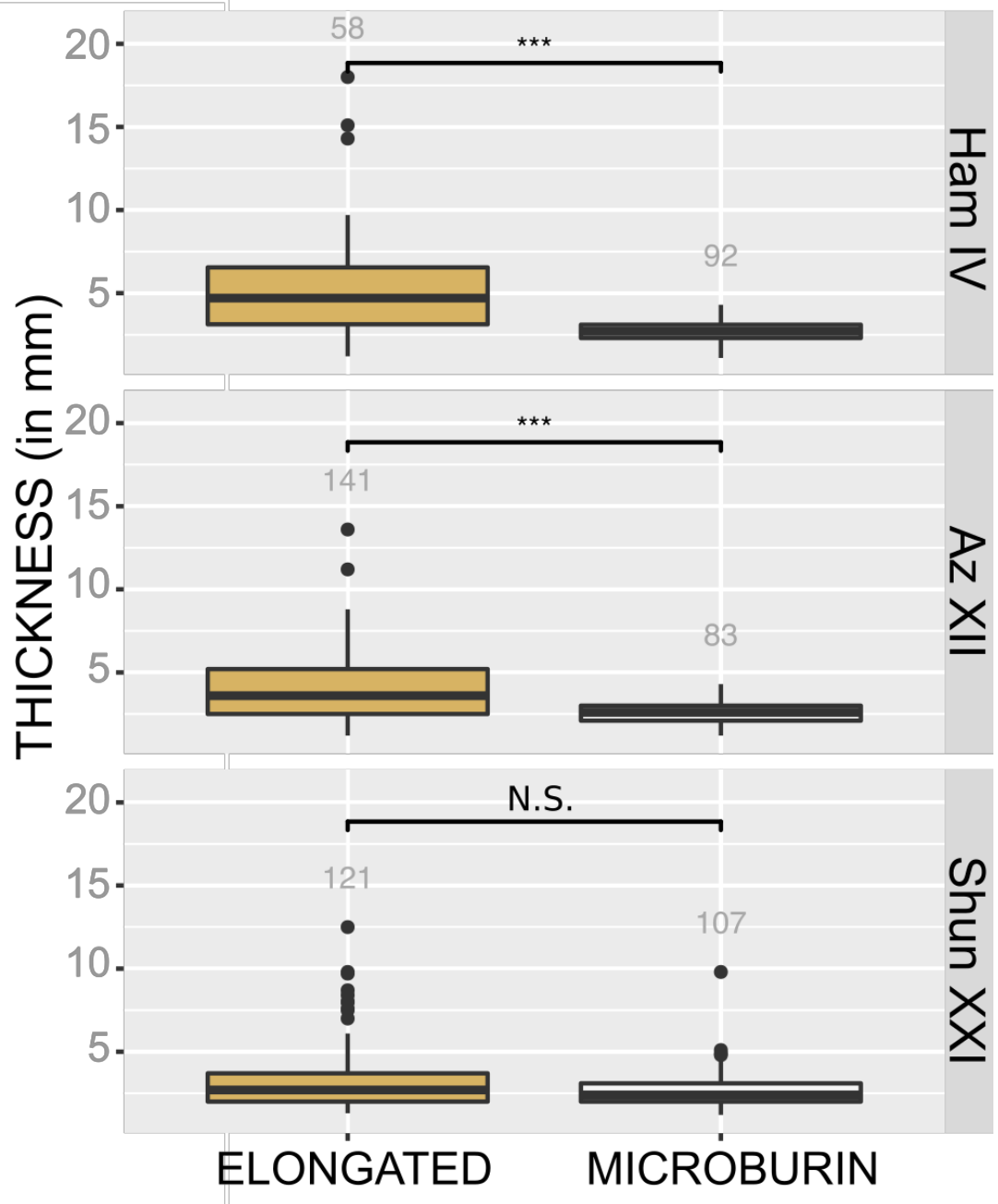

TYPE OF BLANK

Figure 10. Comparisons of width and thickness of microburins and elongated blanks at Hamifgash IV, Azariq XII and Shunera XXI. Az - Azariq; Shun - Shunera; Ham Hamifgash. 

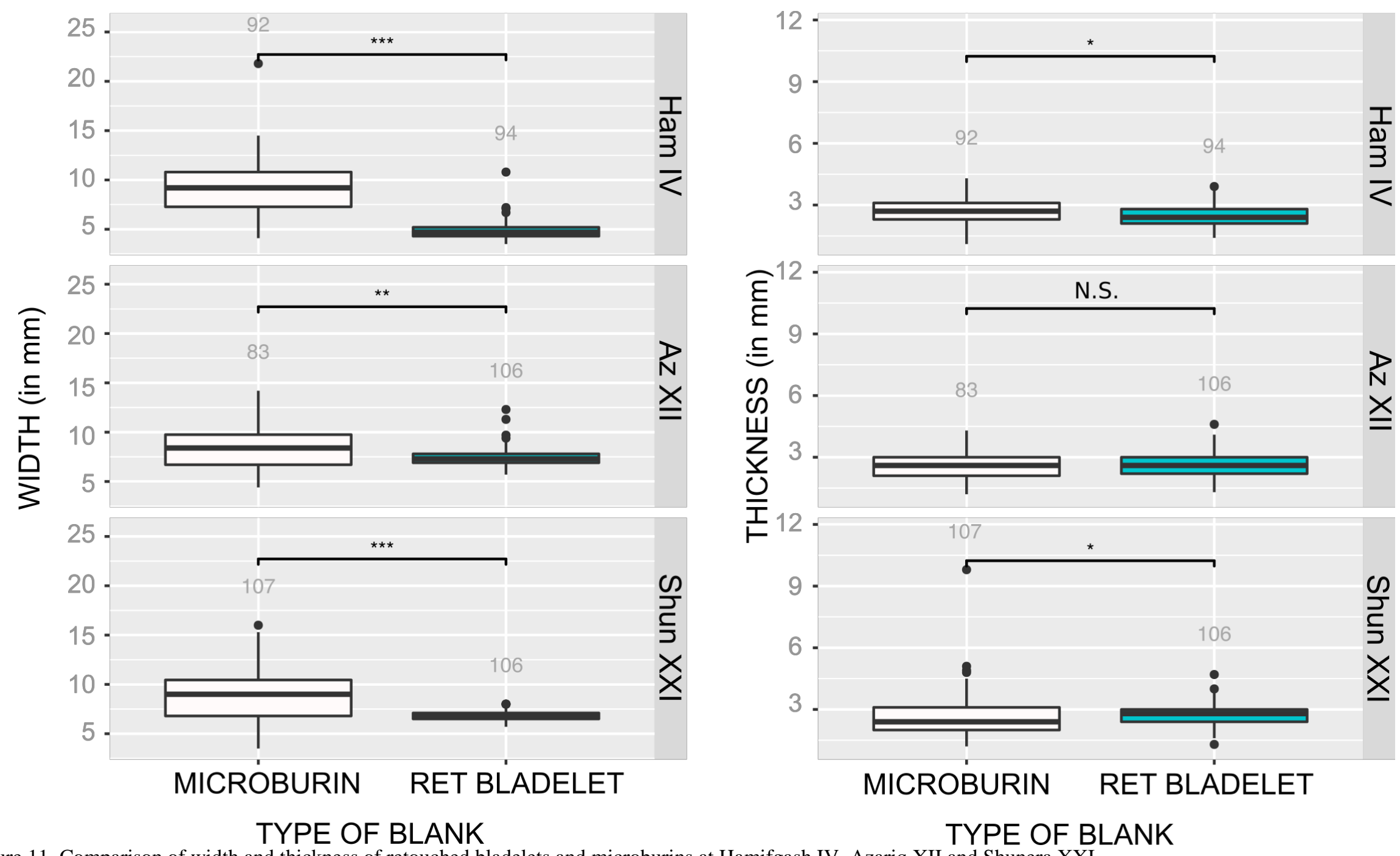

Figure 11. Comparison of width and thickness of retouched bladelets and microburins at Hamifgash IV, Azariq XII and Shunera XXI. 


\subsection{Characteristics of retouched tools}

Retouched tools are numerous (11-24\% of the assemblages, excluding debris) within all assemblages (Goring-Morris 1987). The majority are microliths (83-95\%). Except at Azariq XIII, where fine (Ouchtata) retouch dominates, at all other sites, backing predominates, whether or not in conjunction with the microburin technique: finely retouched bladelets at Azariq XIII, micropoints at Azariq IV, scalene and arch-backed bladelets at Hamifgash IV and Azariq XII, trapeze and rectangles at Azariq XVI, and Ramon points (straight pr slightly concave backed and obliquely truncated) at Shunera XXI (Goring-Morris 1987; Marder 2002).

Most of the retouched bladelets from Azariq XIII are fragmented, making metric comparisons with other assemblages difficult. However, the dimensions of almost complete blanks were recorded following several intervals that allowed their approximate comparisons with retouched blanks from other assemblages (see Figure 12). Retouched blanks from Azariq XIII are conspicuous in comparison to the retouched blanks from the other sites by being much narrower and more slender.
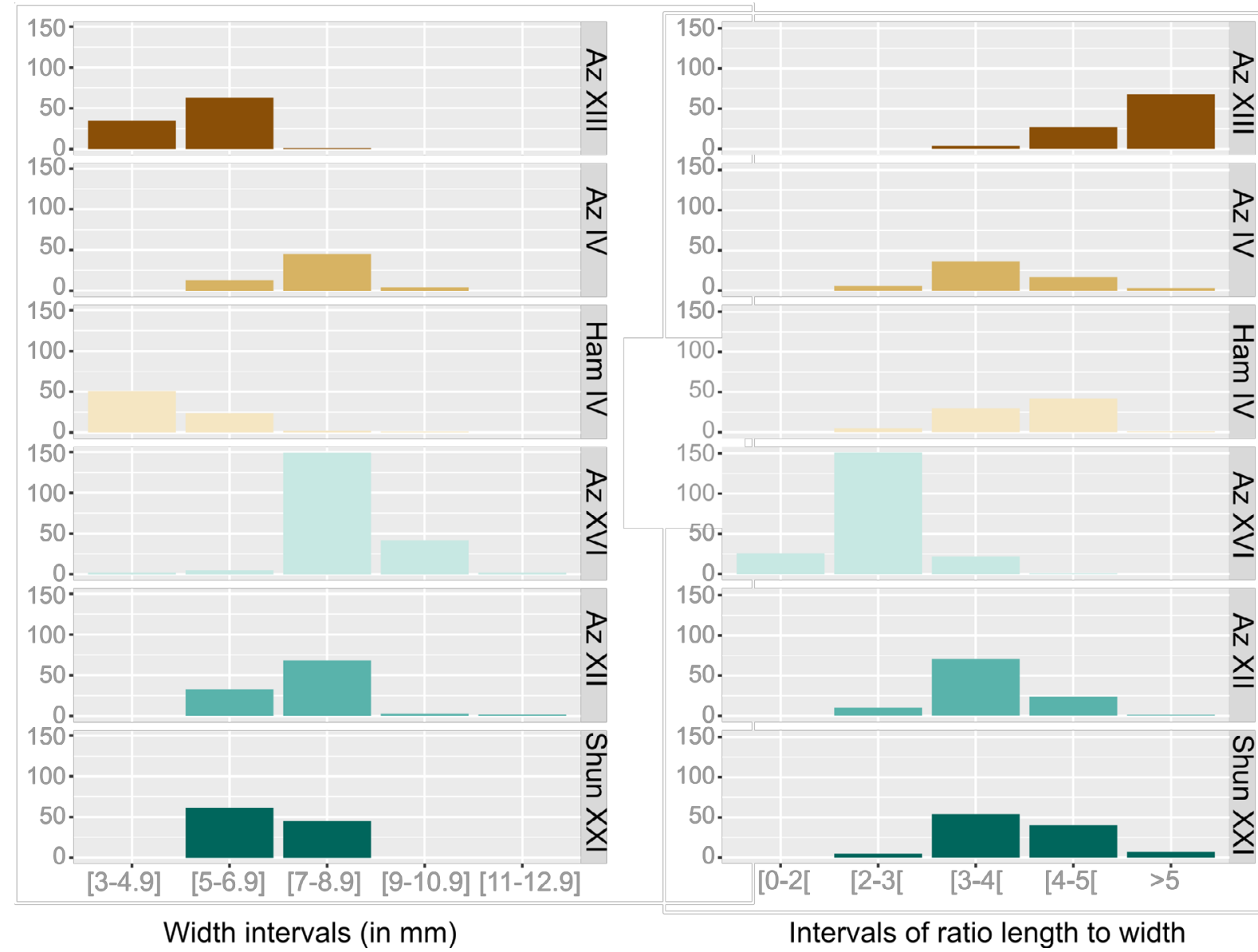

Figure 12. Comparisons of dimensions of retouched bladelets. Az - Azariq; Shun - Shunera; Ham - Hamifgash.

Microliths from the different assemblages display distinct dimensions (see Table 13 and Figure 13). The distributions of the widths is different for all assemblages except between Azariq XII and Azariq IV (Kruskal-Wallis chi-square $=313.51$, df $=4$, p-value $<2.2 \mathrm{e}-16$, followed by p-values <.05 for the Dunn's test). However, this may reflect site-specific characteristics rather than reflecting any particular entity. Microlith dimensions from many assemblages associated with the same entity usually display significant variability (GoringMorris 1987). However, perhaps more significant, despite this variation in dimensions, the 
widths in all assemblages show a small coefficient of variation (from $7 \%$ at Shunera XXI to $20 \%$ at Hamifgash IV), indicating that control of the width was probably the most important variable in the manufacture of microliths, likely related to hafting considerations.

Table 13. Main statistics for complete microliths. Abbreviations: CV $=$ coefficient of variation $=\mathrm{sd} / \mathrm{mean} * 100$

\begin{tabular}{|c|c|c|c|c|c|c|c|c|c|c|c|}
\hline ite & $\begin{array}{l}\stackrel{+}{\mathbf{L}} \\
\overline{\mathbf{O}} \\
\mathbf{U}\end{array}$ & 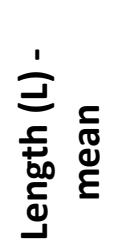 & D্ & $\begin{array}{l}\text { 己 } \\
\stackrel{*}{z}\end{array}$ & 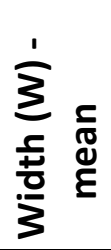 & $\begin{array}{l}\text { D } \\
3\end{array}$ & $\frac{\overline{3}}{3}$ & 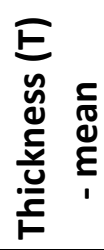 & $\begin{array}{l}\text { D্ } \\
\vdash\end{array}$ & 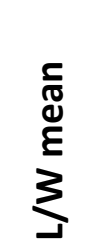 & $\sum_{3}^{0}$ \\
\hline Azariq IV & 26 & 29.21 & 3.9 & $13.40 \%$ & 7.63 & 0.96 & $12.60 \%$ & 3.31 & 0.93 & 3.89 & 0.71 \\
\hline Azariq XII & 106 & 26.97 & 3.17 & $11.80 \%$ & 7.47 & 0.95 & $12.70 \%$ & 2.64 & 0.58 & 3.65 & 0.54 \\
\hline Azariq XVI & 200 & 19.61 & 4.51 & $23.00 \%$ & 8.35 & 0.96 & $11.50 \%$ & 2.62 & 0.6 & 2.35 & 0.5 \\
\hline Hamifgash IV & 72 & 19.1 & 2.21 & $11.60 \%$ & 4.86 & 0.98 & $20.20 \%$ & 2.45 & 0.43 & 4 & 0.53 \\
\hline Shunera XXI & 106 & 26.58 & 4.35 & $16.40 \%$ & 6.81 & 0.52 & $7.60 \%$ & 2.75 & 0.58 & 3.91 & 0.64 \\
\hline
\end{tabular}
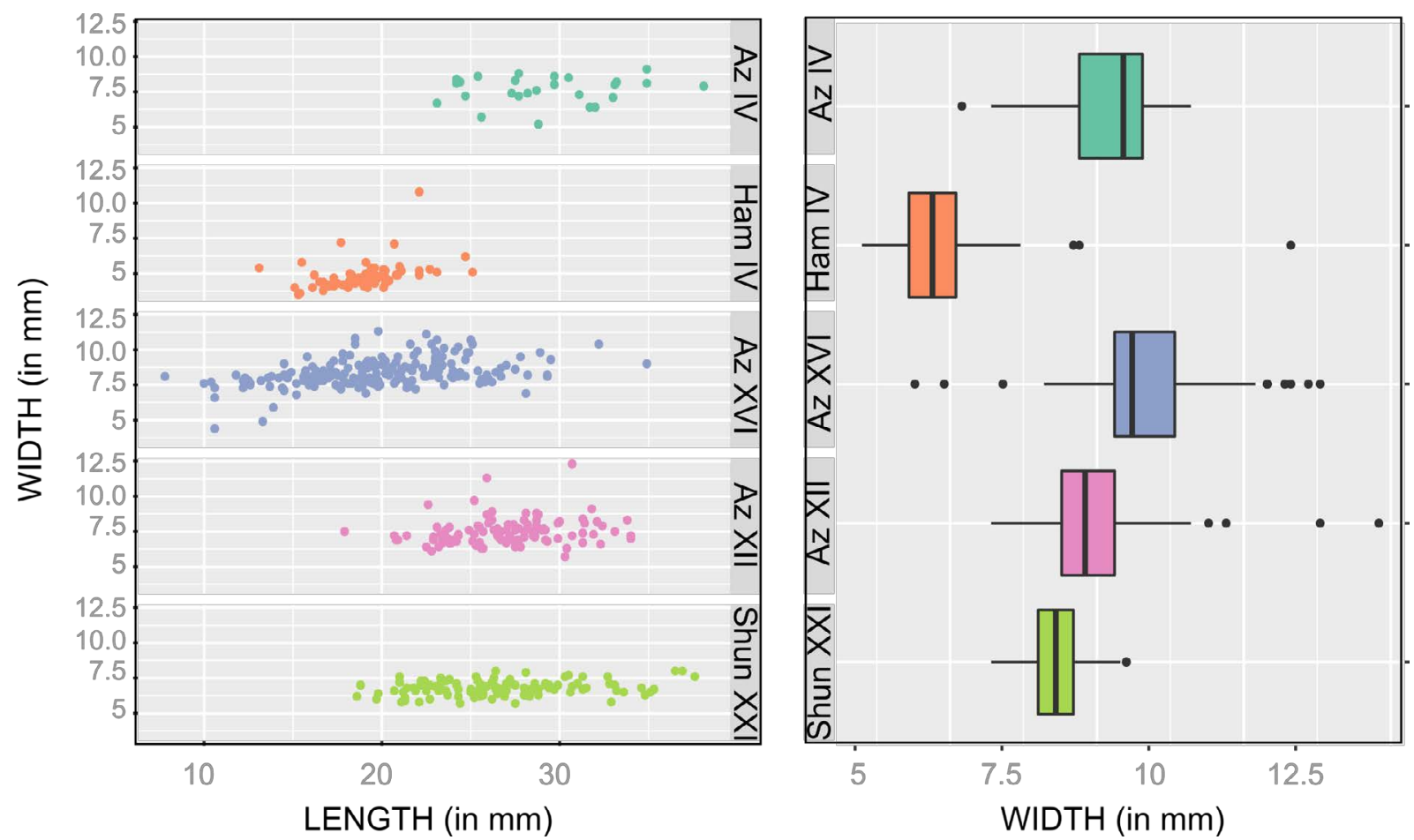

Figure 13. Biplot of lengths and widths and boxplot of widths of complete retouched bladelets. Az - Azariq; Shun - Shunera; Ham - Hamifgash.

Characteristics of the proximal parts enable division of the microlith assemblages into two groups: one includes more or less systematic removal of the platform and bulb (Hamifgash IV, Azariq XVI and Azariq XII, respectively 89\%, 95\% and 78\% of the microliths), as opposed to those with less removal of the proximal extremities (Azariq XIII, Azariq IV and Shunera XXI, respectively 8\%, 33\% and 14\%).

\section{Discussion}

Table 14 summarises the characteristics of the different assemblages studied. 
Table 14. Main characteristics of the lithic assemblages studied. Abbreviations: F - flint, local sources; C - chalcedony, more distant sources; CTE - core trimming element; B - blades; Bt - bladelets; sd - standard deviation;

\begin{tabular}{|c|c|c|c|c|c|c|}
\hline & Azariq XIII & Azariq IV & Hamifgash IV & Azariq XVI & Azariq XII & Shunera XXI \\
\hline $\begin{array}{l}\text { Cultural entity } \\
\text { (years cal. BP) }\end{array}$ & $\begin{array}{c}\text { Masraqan } \\
(24,000-19,000)\end{array}$ & $\begin{array}{c}\text { Kebaran } \\
(21,000-18,000)\end{array}$ & $\begin{array}{c}\text { Nizzanan } \\
(20,000-18,000)\end{array}$ & $\begin{array}{c}\text { Geometric Kebaran } \\
(17,500-14,500)\end{array}$ & $\begin{array}{c}\text { Mushabian } \\
(17,000-14,500 \mathrm{k})\end{array}$ & $\begin{array}{c}\text { Ramonian } \\
(16,000-15,000)\end{array}$ \\
\hline $\begin{array}{l}\text { Raw material } \\
\text { (flint, chalcedony) }\end{array}$ & $\mathrm{F}$ & $\mathrm{F}$ & $\mathrm{F}$ & $\mathrm{F}$ & $\mathrm{F}$ & $\mathrm{F}, \mathrm{C}$ \\
\hline \multicolumn{7}{|l|}{ General count (\% without chips) } \\
\hline cores & $40(0.8 \%)$ & $18(0.6 \%)$ & $29(1.3 \%)$ & $32(0.4 \%)$ & $73(1.2 \%)$ & $26(0.4 \%)$ \\
\hline CTE'S & $324(6.5 \%)$ & $99(3.4 \%)$ & $170(7.5 \%)$ & $147(2.0 \%)$ & $261(4.1 \%)$ & $74(1.3 \%)$ \\
\hline blades and frags & 1677 (15.9\%) & $482(16.4 \%)$ & $482(16.4 \%)$ & $2350(32.5 \%)$ & $1872(29.8 \%)$ & $2521(42.8 \%)$ \\
\hline microburins & - & 2 & $262(11.6 \%)$ & $30(0.4 \%)$ & 350 (5.6\%) & $594(10.1 \%)$ \\
\hline retouched tools & $1188(23.9 \%)$ & $230(7.8 \%)$ & $336(14.9 \%)$ & $1251(17.3 \%)$ & $1353(21.5 \%)$ & $1165(19.8 \%)$ \\
\hline \multicolumn{7}{|l|}{ Cores \& CTE's } \\
\hline$N$ - and $W$-fronted & $\mathrm{N}$ & $\mathrm{N} \& \mathrm{~W}$ & $\mathrm{~N} \& \mathrm{~W}$ & W & W & W \\
\hline main CTE's & $\begin{array}{l}\text { crested and core } \\
\text { tablets }\end{array}$ & $\begin{array}{l}\text { crested and } \\
\text { core tablets }\end{array}$ & $\begin{array}{l}\text { management } \\
\text { convexities }\end{array}$ & $\begin{array}{c}\text { crested, core tablets, } \\
\text { overpassed }\end{array}$ & $\begin{array}{c}\text { crested, core tablets, } \\
\text { overpassed }\end{array}$ & $\begin{array}{c}\text { crested, core tablets, } \\
\text { overpassed }\end{array}$ \\
\hline \multicolumn{7}{|c|}{ Elongated blanks - morphometric characteristics } \\
\hline blades $(B) \&$ bladelets $(B t)$ & $\mathrm{Bt}$ & $\mathrm{Bt}$ & B & $\mathrm{Bt}$ & $\mathrm{B} \& \mathrm{Bt}$ & Bt \\
\hline mean width $(\mathrm{mm})(\mathrm{sd})$ & $7.9(2.6)$ & $12.1(5)$ & $12.4(4.5)$ & 13.5 (4.9) & $13.3(4.2)$ & $11.4(4.1)$ \\
\hline mean length to width ratio (sd) & $4.3(1.2)$ & $3.1(0.7)$ & $3.2(1.1)$ & $3.1(0.8)$ & $3.1(0.6)$ & $3(0.7)$ \\
\hline unidirectional scar pattern & $80 \%$ & $65 \%$ & $72 \%$ & $66 \%$ & $71 \%$ & $78 \%$ \\
\hline bidirectional scar pattern & $3 \%$ & $12 \%$ & $6 \%$ & $14 \%$ & $12 \%$ & $10 \%$ \\
\hline distally convergent & $37 \%$ & $36 \%$ & $36 \%$ & $33 \%$ & $37 \%$ & $46 \%$ \\
\hline regular parallel & $23 \%$ & $14 \%$ & $14 \%$ & $11 \%$ & $6 \%$ & $5 \%$ \\
\hline longitudinal flat profile & $7 \%$ & $22 \%$ & $19 \%$ & $11 \%$ & $8 \%$ & $13 \%$ \\
\hline longitudinal curved profile & $43 \%$ & $23 \%$ & $31 \%$ & $35 \%$ & $38 \%$ & $34 \%$ \\
\hline \multicolumn{7}{|l|}{ Elongated blanks - proximal part } \\
\hline plain butts & $30 \%$ & $72 \%$ & $68 \%$ & $44 \%$ & $29 \%$ & $39 \%$ \\
\hline faceted or dihedral butts & $0 \%$ & $4 \%$ & $0 \%$ & $0 \%$ & $1 \%$ & $0 \%$ \\
\hline linearor punctiform butts & $70 \%$ & $24 \%$ & $29 \%$ & $56 \%$ & $70 \%$ & $59 \%$ \\
\hline abrasion & $82 \%$ & $42 \%$ & $21 \%$ & $60 \%$ & $75 \%$ & $82 \%$ \\
\hline
\end{tabular}




\subsection{Lithic variability in the Early and Middle Epipalaeolithic of the Negev}

Comparative analysis highlighted a number of shared features among these assemblages: the primary focus on the production of small elongated, often distally convergent blanks, from mainly unidirectional cores with plain striking platforms, as well as the high percentage of retouched tools dominated by microliths. Beyond typological differences, this study also highlights some inter-assemblage differences. Azariq XIII clearly stands apart with the use of mostly $\mathrm{N}$-fronted cores for the production of very slender incurvate bladelets, the probable use of soft stone hammers, the use of systematic abrasion of the striking platforms and the use of fine (Ouchtata) retouch for the manufacture of retouched tools continuing the previous Upper Palaeolithic Ahmarian tradition of minimal modification of the blanks (Belfer-Cohen \& Goring-Morris 2002; Davidzon \& Goring-Morris 2003), in contrast to the other Early EP industries.

The other five assemblages present more similar characteristics. However, Early Epipalaeolithic Azariq IV and Hamifgash IV include both $\mathrm{N}$ - and $\mathrm{W}$-fronted cores for the production of blades or bladelets usually with a flat longitudinal profile and abrasion of the striking platform is not systematic. The main differences between these two assemblages are typological: at Azariq IV relatively wide and thick microliths were produced using abrupt retouch, without removing the platform or the bulb, while at Hamifgash IV small and narrow microliths were produced using the microburin technique removing the proximal part of the blank, as well as backed retouch.

The Middle Epipalaeolithic assemblages (Azariq XVI, Azariq XII and Shunera XXI) are characterised mainly by $\mathrm{W}$-fronted cores for bladelet production, which were then transformed into microliths using backed retouch. Azariq XVI is notable for the higher frequency of bidirectional debitage, which likely reflects the use of an opposed platform for the maintenance of convexities (Marder 2002), the lower percentage of abrasion of the platform, and the absence of the microburin technique. However, as the aim was to produce trapeze and rectangles with near $90^{\circ}$ angles, the microburin technique would not have been efficient (see also Marder 2002). Compared to Azariq XII, Shunera XXI is characterised by smaller and thinner elongated blanks, retouched using the microburin technique at the distal extremity, which did not lead to the removal of the proximal part of the blanks.

\subsection{Discussing contacts between the southern Levant and the Nile Valley}

The main characteristics of the lithic assemblages from E71K18C and E71K20 (for a detailed description, see Leplongeon 2017), are summarised in Table 15 and can be compared with data from Table 14. The Silsilian (E71K20) is dated to 17,500-19,000 cal BP (Schild \& Wendorf 2010), while the Afian (E71K18) is attributed to the period 14,500-16,500 cal BP (Schild \& Wendorf 2010). Although their chronological attribution is debated (Leplongeon 2017), there is no new information that enables us to question the original chronological attribution. As a working hypothesis they may be considered contemporaneous respectively with the Early EP and Middle EP.

All assemblages are oriented towards the production of elongated blanks. Retouched tools are numerous, and among them, backed retouch is dominant. The two Nile Valley sites show evidence for the use of the microburin technique, which is also used within the EP of the Negev. However, despite these very broad similarities, striking differences are observed in core and platform preparation. Elongated blanks tend to be larger and less elongated at E71K18C and E71K20, bidirectional scar patterns tend to have higher frequencies, which is also reflected in the types of cores. Faceted or dihedral platforms are much more frequent, and abrasion is less common. The low number of microburins, associated with a low microburin index, indicates either occasional use of the microburin technique or off-site production of 
tools using the microburin technique. In addition, typological differences are also very marked. Beyond the typological variability, standardisation within categories is lower in the Nile Valley sites (e.g., coefficient of variation [C.V.] of width of microliths) compared with the Negev sites.

Table 15. Main characteristics of the assemblages of E71K18C and E71K20 (After Leplongeon, 2017). Abbreviations: CTE - core trimming element.

\begin{tabular}{|c|c|c|}
\hline & $\mathrm{E} 71 \mathrm{~K} 20$ & E71K18C \\
\hline Cultural entity & Silsilian ( 18,700-17,500cal BP?) & Afian ( 14,500-16,400 cal BP?) \\
\hline Raw material & flint, local sources & flint, local sources \\
\hline \multicolumn{3}{|l|}{ General count (\% without chips) } \\
\hline cores & $148(2.5 \%)$ & $334(3.3 \%)$ \\
\hline CTE's & $244(4.1 \%)$ & $156(1.6 \%)$ \\
\hline blades and frags & 2037 (34.2\%) & $2240(22.4 \%)$ \\
\hline microburins & $46(0.8 \%)$ & $379(3.9 \%)$ \\
\hline retouched tools & 395 (6.6\%) & $1674(16.7 \%)$ \\
\hline Technique & hard and soft hammerstone? & hard hammerstone? \\
\hline \multicolumn{3}{|l|}{ Cores and CTE's } \\
\hline$N$ - and $W$-fronted & W & W \\
\hline main CTE's & $\begin{array}{l}\text { mainly crested and overpassed } \\
\text { products }\end{array}$ & few, mainly overpassed products \\
\hline \multicolumn{3}{|c|}{ Elongated blanks - morphometric characteristics } \\
\hline blades \& bladelets & Blades or bladelets & Blades or bladelets \\
\hline mean width $(\mathrm{mm})(\mathrm{sd})$ & $14.4(3.9)$ & $13.3(4.2)$ \\
\hline mean length to width ratio (sd) & $2.8(0.6)$ & $2.8(0.6)$ \\
\hline unidirectional scar pattern & $47 \%$ & $63 \%$ \\
\hline bidirectional scar pattern & $27 \%$ & $20 \%$ \\
\hline distally convergent & $43 \%$ & $40 \%$ \\
\hline regular parallel & $15 \%$ & $34 \%$ \\
\hline longitudinal flat profile & $18 \%$ & $25 \%$ \\
\hline \multirow[t]{2}{*}{ longitudinal curved profile } & $35 \%$ & $24 \%$ \\
\hline & E71K20 & E71K18C \\
\hline \multicolumn{3}{|l|}{ Elongated blanks - proximal part } \\
\hline plain butts & $61 \%$ & $39 \%$ \\
\hline faceted or dihedral butts & $7 \%$ & $39 \%$ \\
\hline linear orpunctiform butts & $30 \%$ & $20 \%$ \\
\hline abrasion & $54 \%$ & $18 \%$ \\
\hline \multicolumn{3}{|l|}{ Use of the microburin technique } \\
\hline presence & YES & YES \\
\hline Restricted microburin index & 12 & 26 \\
\hline $\begin{array}{l}\text { significant differences between } \\
\text { microburin and elongated }\end{array}$ & YES & YES \\
\hline $\begin{array}{l}\text { significant differences between } \\
\text { microburin and retouched } \\
\text { (backed) }\end{array}$ & NO & NO \\
\hline \multicolumn{3}{|l|}{ Retouched tools } \\
\hline Main types & $\begin{array}{l}\text { micro- and macro-lithic } \\
\text { retouched tools, mainly backed } \\
\text { pieces, esp. distally backed pieces }\end{array}$ & $\begin{array}{l}\text { mainly microlithic, truncations, backed } \\
\text { bladelets and trapezes or triangles }\end{array}$ \\
\hline mean width $(\mathrm{mm})(\mathrm{sd}-\mathrm{CV})$ & backed pieces: 12.5 (3.4 - 27\%) & $\begin{array}{l}\text { truncations: } 12.2(2.8-23 \%) \text {; trapezes } \\
\text { or triangles: } 10.8(1.7-16 \%)\end{array}$ \\
\hline type retouch & abrupt & abrupt \\
\hline $\begin{array}{l}\text { removal of proximal part for } \\
\text { backed bladelets }\end{array}$ & $50 \%$ & $72 \%$ \\
\hline
\end{tabular}


The only possible indicator of links between the Nile Valley and the Levant at that time would thus be the presence of the microburin technique. The first occurrence of its use in the Nile Valley is in the Silsilian and Afian industries (ca. 19,000-14,500 cal BP). However, while the first evidence for habitual use of the MBT in the Negev is found in the Nizzanan site of Hamifgash IV (ca. 20,000-18,000cal BP), earlier evidence within the EP of the Levant is found in the Transjordanian Nebekian entity, dated ca. 25,000-22,000 cal BP, thus suggesting an East-West diffusion of the microburin technique in the Levant (e.g., GoringMorris 1995). While further diffusion of the microburin technique from the Negev to the Nile Valley may be postulated, the marked typo-technological differences between both groups of assemblages render it unlikely. In addition, both Nile Valley assemblages display evidence for the manufacture of notched blades or bladelets in addition to abundant backed pieces, so the microburin technique may have been independently invented there.

The above comparison between Negev and Nile Valley assemblages has failed to highlight compelling evidence for contacts between the two regions at the end of the Pleistocene. Although contacts (direct or indirect) may have occurred, this is currently not visible in the archaeological record. As noted, some of these results may be due to inherent limits of the data: geographical distances between the sites, intra-entity variability not accounted for in this study, lack of sufficient chronological resolution, or a combination of these. Despite these limitations, the techno-complexes in the two areas appear very distinct.

Current archaeological evidence therefore does not support any contacts between populations between the Levant and the Nile Valley at the end of the Pleistocene. Only the above-mentioned surface collections at Helwan would signal technical diffusions between the Levant and the Nile Delta area at the end of the Pleistocene. However, these collections were made according to the 'beautiful piece' criteria, and they seem to be characterised by considerable typological diversity. Some of the backed points are consistent with an attribution to the Ramonian points or Mushabian arch-backed bladelets (Schmidt 1996, figs 34). Given their geographical location, they might correspond to a westward expansion of the 'territory' of the Mushabian and Ramonian, rather than contacts between two different populations. In the absence of numbers and context, it is not possible to interpret further these similarities. It is worth mentioning that palaeoenvironmental data for the Delta area still lack sufficient chronological resolution. Was the Nile Delta a stronger palaeoenvironmental barrier than previously thought? This would be consistent with recent palaeoenvironmental data from this region (e.g., Muhs et al. 2013; Revel et al. 2010). In addition, the lake hypothesis for the Late Pleistocene Nile (Vermeersch \& Van Neer 2015) would suggest that the Nile Valley would not have acted as a geographically continuous but discontinuous refuge area, perhaps contributing to isolating populations living up-river from northern populations. Future comparative analyses between the southern Levant and the Nile Valley may help to further discuss the topic of contacts between the Nile Valley and the Levant at the end of the Pleistocene, while detailed comparisons with the north-western African record may help to test hypotheses of east-west (or west-east) technical diffusions.

\section{Acknowledgments}

This research project has received funding from the European Union's Horizon 2020 research and innovation programme under the Marie Sklodowska-Curie grant agreement No 655459, from the Fyssen Foundation (grants to AL) and from the French National Research Agency project 'Big Dry' ID ANR14-CE31-0023-03. We would like to thank the department of Ancient Egypt and Sudan of the British Museum for permission to study the lithic assemblages of E71K18C and E71K20. Many thanks to Erella Hovers for her support and valuable comments throughout this research. We thank S. Kadowaki, three anonymous 
reviewers and Otis Crandell, editor of Journal of Lithic Studies, for their useful comments which have significantly improved the manuscript.

\section{References}

Baruch, U. \& Goring-Morris, N. 1997, The arboreal vegetation of the Central Negev Highlands, Israel, at the end of the Pleistocene: Evidence from archaeological charred wood remains. Vegetation History and Archaeobotany, 6(4): 249-259. doi:10.1007/BF01370446

Bar-Yosef, O. 2017, Locals and Foreigners in the Levant during the Pleistocene. In: Vocation préhistoire. Hommage à Jean-Marie Le Tensorer (Otte, M., Ed.), Etudes et Recherches Archéologiques de l’Université de Liège (ERAUL) Vol. 148, Université de Liège, Liège: p. 25-42.

Bar-Yosef, O. 2013, Nile Valley-Levant interactions: An eclectic review. In: Neolithisation of Northeastern Africa (Shirai, N., Ed.), Studies in Early Near Eastern Production, Subsistence, and Environment Vol. 16, Ex Oriente, Berlin: p. 237-248.

Bar-Yosef, O. 1987, Pleistocene connexions between Africa and Southwest Asia: an archaeological perspective. African Archaeological Review, 5(1): 29-38. doi:10.1007/BF01117080

Bar-Yosef, O. 1970, The Epi-Palaeolithic Cultures of Palestine. Doctoral Thesis at The Hebrew University of Jerusalem, Jerusalem, 402 p.

Bar-Yosef, O. \& Belfer, A. 1977, The Lagaman Industry. In: Prehistoric investigations in Gebel Maghara, Northern Sinai (Bar-Yosef, O. \& Phillips, J. L., Eds.), QEDEM, Monographs of the Institute of Archaeology Vol. 7, The Hebrew University of Jerusalem, Jerusalem: p. 42-84.

Bar-Yosef, O. \& Phillips, J.L. (Eds.) 1977, Prehistoric Investigations in Gebel Maghara, Northern Sinai. QEDEM, Monographs of the Institute of Archaeology Vol. 7, The Hebrew University of Jerusalem, Jerusalem, 269 p.

Belfer-Cohen, A. \& Goring-Morris, A.N. 2014, The Upper Palaeolithic and Earlier Epipalaeolithic of Western Asia. In: The Cambridge World Prehistory, Vol. 3 (Renfrew, C. \& Bahn, P., Eds.), Cambridge University Press, Cambridge: p. 1381-1407.

Belfer-Cohen, A. \& Goring-Morris, N. 2002, Why Microliths? Microlithization in the Levant. In: Thinking small: global perspective on Microlithization (Elston, R. G. \& Kuhn, S. L., Eds.), Archeological papers of the American Anthropological Association Vol. 12, American Anthropological Association, Arlington: p. 57-68.

Ben-David, R. \& Yair, A. 2008, Geological Background of the Nizzana Area. In: Arid Dune Ecosystems: The Nizzana Sands in the Negev Desert (Breckle, S.-W., Yair, Aaron, \& Veste, M., Eds.), Ecological Studies Springer Berlin Heidelberg, Berlin, Heidelberg: p. 9-15. doi:10.1007/978-3-540-75498-5_1

Butzer, K.W. 1997, Late Quaternary problems of the Egyptian Nile : stratigraphy, environments, prehistory. Paléorient, 23(2): 151-173. doi:10.3406/paleo.1997.4658

Carlson, D.L. 2017, Quantitative Methods in Archaeology Using R. Cambridge Manuals in Archaeology Cambridge University Press, Cambridge, 431 p. 
Close, A.E., Wendorf, F. \& Schild, R. 1979, The Afian: a study of stylistic variation in a Nilotic industry. Department of Anthropology, Southern Methodist University, Dallas, $301 \mathrm{p}$.

Davidzon, A. \& Goring-Morris, A.N. 2003, Sealed in Stone: The Upper Palaeolithic Early Ahmarian Knapping Method in the Light of Refitting Studies at Nahal Nizzana XIII, Western Negev, Israel. Mitekufat Haeven: Journal of the Israel Prehistoric Society, 33: 75-205.

Debono, F. 1948, Le paléolithique final et le mésolithique à Hélouan. Annales du Service des Antiquités de l'Egypte, 48: 629-637.

Dunn, O.J. 1964, Multiple Comparisons Using Rank Sums. Technometrics, 6(3): 241-252. doi:10.2307/1266041

Enzel, Y., Amit, R., Dayan, U., Crouvi, O., Kahana, R., Ziv, B. \& Sharon, D. 2008, The climatic and physiographic controls of the eastern Mediterranean over the late Pleistocene climates in the southern Levant and its neighboring deserts. Global and Planetary Change, 60(3): 165-192. doi:10.1016/j.gloplacha.2007.02.003

Forster, P., Romano, V., Olivieri, A., Achilli, A., Pala, M., Battaglia, V., Fornarino, S., AlZahery, N., Scozzari, R., Cruciani, F., Behar, D.M., Dugoujon, J.M., Coudray, C., Santachiara-Benerecetti, A.S.B., Semino, O., Bandelt, H.J. \& Torroni, A. 2007, Timing of a Back-Migration into Africa [with Response]. Science, 316(5821): 50-53. doi:10.2307/20035937

Goder-Goldberger, M. 2013, The Khormusan: Evidence for an MSA East African industry in Nubia. Quaternary International, 300: 182-194. doi:10.1016/j.quaint.2012.11.031

Goder-Goldberger, M., Ginat, H., Ragolski, G., Seri, G. \& Abadi, I. 2017, Middle Palaeolithic find spots with Nubian cores from the Southern Negev and the Arava, Israel. Journal of Lithic Studies, 4(1):. doi:10.2218/jls.v4i1.1688

Goder-Goldberger, M., Gubenko, N. \& Hovers, E. 2016, "Diffusion with modifications": Nubian assemblages in the central Negev highlands of Israel and their implications for Middle Paleolithic inter-regional interactions. Quaternary International, 408(Part B): 121-139. doi:10.1016/j.quaint.2016.02.008

Goring-Morris, A.N. 1987, At the edge: terminal Pleistocene hunter-gatherers in the Negev and Sinai. British Archaeological Reports International Series Vol. 361, BAR, Oxford, $526 \mathrm{p}$.

Goring-Morris, A.N. 1995, Complex hunter-gatherers at the end of the Paleolithic (20,00010,000 BP). In: The archaeology of society in the Holy Land (Levy, T. E., Ed.), Leicester University Press, London: p. 141-168.

Goring-Morris, A.N. 2017, Loess, Dunes, and Human Activities. In: Quaternary of the Levant. Environments, Climate Change, and Humans (Enzel, Y. \& Bar-Yosef, O., Eds.), Cambridge University Press, Cambridge: p. 493-504.

Goring-Morris, A.N. 1993, Shunera Dunes. In: The New Encyclopedia of Archaeological Excavations in the Holy Land (Stern, E., Ed.), Israel Exploration Society and Simon \& Schuster, Jerusalem and New York: p. 1380-1382.

Goring-Morris, A.N. \& Belfer-Cohen, A. 2003, Structures and dwellings in the upper and Epi-palaeolithic (ca. 42-10k BP) Levant: Profane and symbolic uses. In: Perceived Landscapes and Built Environments. The cultural geography of Late Paleolithic 
Eurasia (Vasil'ev, S. A., Soffer, O., \& Kozlowski, J., Eds.), British Archaeological Reports International Series Vol. 1122, BAR, Oxford: p. 65-82.

Goring-Morris, A.N. \& Belfer-Cohen, A. 1997, The articulation of cultural processes and Late Quaternary environmental changes in Cisjordan. Paléorient, 23(2): 71-93.

Goring-Morris, A.N. \& Belfer-Cohen, A. 2017, The Early and Middle Epipalaeolithic of Cisjordan. In: Quaternary of the Levant. Environments, Cliamte Change, and Humans (Enzel, Y. \& Bar-Yosef, O., Eds.), Cambridge University Press, Cambridge: p. 639-650.

Goring-Morris, A.N. \& Goldberg, P. 1990, Late Quaternary dune incursions in the southern levant: Archaeology, chronology and palaeoenvironments. Quaternary International, 5: 115-137. doi:10.1016/1040-6182(90)90031-X

Goring-Morris, A.N., Hovers, E. \& Belfer-Cohen, A. 2009, The dynamics of Pleistocene and Early Holocene settlement patterns and human adaptations in the Levant: an overview. In: Transitions in Prehistory: Essays in Honor of Ofer Bar-Yosef (Shea, J. J. \& Lieberman, D. E., Eds.), Oxbow books, Oxford: p. 185-252.

Goring-Morris, A.N., Marder, O., Davidzon, A. \& Ibrahim, F. 1998, Putting Humpty together again: Preliminary observations on refitting studies in the eastern Mediterranean. In: The organization of lithic technology in late glacial and early postglacial Europe (Milliken, S., Ed.), B.A.R., Oxford: p. 149-182.

Goring-Morris, N. \& Davidzon, A. 2006, Straight to the point : Upper paleolithic Ahmarian lithic technology in the levant. Anthropologie (Brno), 44(1): 93-111.

Groucutt, H.S., Petraglia, M.D., Bailey, G., Scerri, E.M., Parton, A., Clark-Balzan, L., Jennings, R.P., Lewis, L., Blinkhorn, J., Drake, N.A. \& others 2015, Rethinking the dispersal of Homo sapiens out of Africa. Evolutionary Anthropology: Issues, News, and Reviews, 24(4): 149-164.

Hendrickx, S. \& Vermeersch, P.M. 2000, Prehistory: From the Palaeolithic to the Badarian culture. In: The Oxford history of ancient Egypt (Shaw, I., Ed.), Oxford University Press, Oxford: p. 17-43.

Henn, B.M., Botigué, L.R., Gravel, S., Wang, W., Brisbin, A., Byrnes, J.K., Fadhlaoui-Zid, K., Zalloua, P.A., Moreno-Estrada, A., Bertranpetit, J., Bustamante, C.D. \& Comas, D. 2012, Genomic Ancestry of North Africans Supports Back-to-Africa Migrations. PLoS Genet, 8(1): e1002397. doi:10.1371/journal.pgen.1002397

Hodgson, J.A., Mulligan, C.J., Al-Meeri, A. \& Raaum, R.L. 2014, Early Back-to-Africa Migration into the Horn of Africa. PLoS Genet, 10(6): e1004393. doi:10.1371/journal.pgen.1004393

Leplongeon, A. 2017, Technological variability in the Late Palaeolithic lithic industries of the Egyptian Nile Valley: The case of the Silsilian and Afian industries. PLOS ONE, 12(12): e0188824. doi:10.1371/journal.pone.0188824

Leplongeon, A. \& Pleurdeau, D. 2011, The Upper Palaeolithic Lithic Industry of Nazlet Khater 4 (Egypt): Implications for the Stone Age/Palaeolithic of Northeastern Africa. African Archaeological Review, 28: 213-236. doi:10.1007/s10437-011-9100-x

Loosdrecht, M. van de, Bouzouggar, A., Humphrey, L., Posth, C., Barton, N., Aximu-Petri, A., Nickel, B., Nagel, S., Talbi, E.H., Hajraoui, M.A.E., Amzazi, S., Hublin, J.-J., Pääbo, S., Schiffels, S., Meyer, M., Haak, W., Jeong, C. \& Krause, J. 2018, Pleistocene 
North African genomes link Near Eastern and sub-Saharan African human populations. Science, 360(6388): 548-553. doi:10.1126/science.aar8380

Maher, L.A., Richter, T. \& Stock, J.T. 2012, The Pre-Natufian Epipaleolithic: Long-term Behavioral Trends in the Levant. Evolutionary Anthropology: Issues, News, and Reviews, 21(2): 69-81. doi:10.1002/evan.21307

Marder, O. 2002, The Lithic technology of Epipaleolithic hunter-gatherers in the Negev: the implications of refitting studies. Ph.D. Thesis at The Hebrew University of Jerusalem, Jerusalem, $603 \mathrm{p}$.

Muhs, D.R., Roskin, J., Tsoar, H., Skipp, G., Budahn, J.R., Sneh, A., Porat, N., Stanley, J.-D., Katra, I. \& Blumberg, D.G. 2013, Origin of the Sinai-Negev erg, Egypt and Israel: mineralogical and geochemical evidence for the importance of the Nile and sea level history. Quaternary Science Reviews, 69: 28-48. doi:10.1016/j.quascirev.2013.02.022

Nielsen, R., Akey, J.M., Jakobsson, M., Pritchard, J.K., Tishkoff, S. \& Willerslev, E. 2017, Tracing the peopling of the world through genomics. Nature, 541(7637): 302-310. doi:10.1038/nature21347

Olivieri, A., Achilli, A., Pala, M., Battaglia, V., Fornarino, S., Al-Zahery, N., Scozzari, R., Cruciani, F., Behar, D.M., Dugoujon, J.M., Coudray, C., Santachiara-Benerecetti, A.S., Semino, O., Bandelt, H.J. \& Torroni, A. 2006, The mtDNA Legacy of the Levantine Early Upper Palaeolithic in Africa. Science, 314(5806): 1767-1770. doi:10.1126/science.1135566

Osypińska, M. \& Osypiński, P. 2016, Animal Exploitation and Behaviour of the Latest Middle Stone Age Societies in the Middle Nile Valley: Archaeozoological and Taphonomic Analysis of Late Pleistocene Fauna from the Affad Basin, Sudan. African Archaeological Review, 33(2): 107-127. doi:10.1007/s10437-016-9220-4

Osypiński, P. \& Osypińska, M. 2016, Optimal adjustment or cultural backwardness? New data on the latest Levallois industries in the Nile Valley. Quaternary International, 408(Part B): 90-105. doi:10.1016/j.quaint.2015.09.033

Pargeter, C. \& Pargeter, J. (2016), Code for Cluster Analysis (Version Update cluster 12 Dec 2016)[R code].

URL: https:/github.com/cpargeter/ClusterAnalysis/blob/master/cluster.R

Pargeter, J. \& Redondo, M. 2016, Contextual approaches to studying unretouched bladelets: A late Pleistocene case study at Sehonghong Rockshelter, Lesotho. Quaternary International, 404(Part B): 30-43. doi:10.1016/j.quaint.2015.08.038

Pennarun, E., Kivisild, T., Metspalu, E., Metspalu, M., Reisberg, T., Moisan, J.-P., Behar, D.M., Jones, S.C. \& Villems, R. 2012, Divorcing the Late Upper Palaeolithic demographic histories of mtDNA haplogroups M1 and U6 in Africa. BMC Evolutionary Biology, 12(1): 234. doi:10.1186/1471-2148-12-234

Peterson, J. 1999, Early Epipaleolithic Settlement Patterns: Insights from the Study of Ground Stone Tools from the Southern Levant. Levant, 31(1): 1-17. doi:10.1179/007589199790217204

Phillips, J.L. \& Butzer, K.W. 1973, A Silsilian occupation site (GS-2B-II) of the Kom Ombo Plain, Upper Egypt: geology, archaeology and paleo-ecology. Quaternaria, 17: 343386. 
Premo, L.S. \& Tostevin, G.B. 2016, Cultural Transmission on the Taskscape: Exploring the Effects of Taskscape Visibility on Cultural Diversity. PLOS ONE, 11(9): e0161766. doi:10.1371/journal.pone.0161766

R Core Team 2016, R: A Language and Environment for Statistical Computing. R Foundation for Statistical Computing, Vienna, Austria, 3569 p. URL: https:/www.R-project.org

Revel, M., Ducassou, E., Grousset, F.E., Bernasconi, S.M., Migeon, S., Revillon, S., Mascle, J., Murat, A., Zaragosi, S. \& Bosch, D. 2010, 100,000 Years of African monsoon variability recorded in sediments of the Nile margin. Quaternary Science Reviews, 29(11-12): 1342-1362. doi:10.1016/j.quascirev.2010.02.006

Revel, M., Ducassou, E., Skonieczny, C., Colin, C., Bastian, L., Bosch, D., Migeon, S. \& Mascle, J. 2015, 20,000 years of Nile River dynamics and environmental changes in the Nile catchment area as inferred from Nile upper continental slope sediments. Quaternary Science Reviews, 130: 200-221. doi:10.1016/j.quascirev.2015.10.030

Roskin, J., Katra, I. \& Blumberg, D.G. 2014, Particle-size fractionation of eolian sand along the Sinai-Negev erg of Egypt and Israel. Geological Society of America Bulletin, 126(12): 47-65. doi:10.1130/B30811.1

Roskin, J. \& Tsoar, H. 2017, Late Quaternary chronologies of the northern Sinai-northwestern Negev dunefield and their palaeoclimatic and palaeoenvironmental implications. In: Quaternary Environments, Climate Change, and Humans in the Levant (Enzel, Y. \& Bar-Yosef, O., Eds.), Cambridge University Press, Cambridge: p. 505-520.

RStudio Team 2015, RStudio: Integrated Development for R. RStudio, Inc., Boston, MA. URL: http://www.rstudio.com/

Sandford, K.S. 1936, Problems of the Nile valley. American Geographical Society, 26(1): 6776.

Schild, R. \& Wendorf, F. 2010, Late Palaeolithic Hunters-Gatherers in the Nile Valley of Nubia and Upper Egypt. In: South-Eastern Mediterranean Peoples between 130,000 and 10,000 Years Ago (Garcea, E. A. A., Ed.), Oxbow Books, Oxford and Oakville: p. 89-125.

Schmidt, K. 1996, Helwan in Egypt-a PPN Site? In: Neolithic Chipped Stone Industries of the Fertile Crescent, and Their Contemporaries in Adjacent Regions (Kozlowski, S. . \& Gebel, H. G., Eds.), Studies in Early Near Eastern Production, Subsistence, and Environment Vol. 3, Ex Oriente, Berlin: p. 127-136.

Smith, P.E.L. 1966, The Late Paleolithic of Northeast Africa in the light of recent research. American Anthropologist, 68(2): 326-355.

Tassie, G.J. 2014, Prehistoric Egypt: Socioeconomic Transformations in Northeast Africa from the Last Glacial Maximum to the Neolithic, 24,000 to 6,000 Cal BP. Golden House Publications, London, 540 p.

Tostevin, G.B. 2012, Seeing Lithics: A Middle-Range Theory for Testing for Cultural Transmission in the Pleistocene. Oxbow Books, Oxford, 608 p.

Underhill, P.A., Passarino, G., Lin, A.A., Shen, P., Mirazón Lahr, M., Foley, R.A., Oefner, P.J. \& Cavalli-Sforza, L.L. 2001, The phylogeography of Y chromosome binary haplotypes and the origins of modern human populations. Annals of Human Genetics, 65(1): 43-62. doi:10.1046/j.1469-1809.2001.6510043.x 
Vaks, A., Bar-Matthews, M., Ayalon, A., Matthews, A., Frumkin, A., Dayan, U., Halicz, L., Almogi-Labin, A. \& Schilman, B. 2006, Paleoclimate and location of the border between Mediterranean climate region and the Saharo-Arabian Desert as revealed by speleothems from the northern Negev Desert, Israel. Earth and Planetary Science Letters, 249(3-4): 384-399. doi:10.1016/j.epsl.2006.07.009

Vermeersch, P.M. 2006, La vallée du Nil et le Sahara oriental : une population préhistorique fluctuante sous l'effet des variations climatiques. Comptes Rendus Palevol, 5(1-2): 255262. doi:10.1016/j.crpv.2005.09.008

Vermeersch, P.M. (Ed.) 2000, Palaeolithic living sites in Upper and Middle Egypt. Egyptian prehistory monographs Vol. 2, Leuven University Press, Leuven, 330 p.

Vermeersch, P.M. (Ed.) 2002, Palaeolithic quarrying sites in Upper and Middle Egypt. Egyptian prehistory monographs Vol. 4, Leuven University Press, Leuven, 365 p.

Vermeersch, P.M., Paulissen, E. \& Huyge, D. 2000, Makhadma 4, a Late Palaeolithic fishing site. In: Palaeolithic Living Sites in Upper and Middle Egypt (Vermeersch, P. M., Ed.), Egyptian Prehistory Monographs Vol. 2, Leuven University Press, Leuven: p. 227-270.

Vermeersch, P.M., Paulissen, E. \& Vanderbeken, T. 2002, Nazlet Khater 4, an Upper Palaeolithic underground chert mine. In: Palaeolithic quarrying sites in Upper and Middle Egypt (Vermeersch, P. M., Ed.), Leuven University Press, Leuven: p. 211-272.

Vermeersch, P.M. \& Van Neer, W. 2015, Nile behaviour and Late Palaeolithic humans in Upper Egypt during the Late Pleistocene. Quaternary Science Reviews, 130: 155-167. doi:10.1016/j.quascirev.2015.03.025

Wendorf, F. \& Schild, R. 1976, Prehistory of the Nile Valley. Studies in Archaeology Academic Press, New York, 404 p. doi:10.1016/C2013-0-11689-3

Wendorf, F. \& Schild, R. 1989, Summary and synthesis. In: The Prehistory of Wadi Kubbaniya, Vol. 3 (Wendorf, F., Schild, R., \& Close, A. E., Eds.), SMU Press, Dallas: p. $768-824$.

Wickham, H. 2009, ggplot2: Elegant Graphics for Data Analysis. Springer-Verlag New York, $213 \mathrm{p}$.

Wright, K.I. 1994, Ground-Stone Tools and Hunter-Gatherer Subsistence in Southwest Asia: Implications for the Transition to Farming. American Antiquity, 59(2): 238-263. doi:10.2307/281929

\section{Supplementary Information}

SI 1. Variables and main indexes used in the study.

SI 2. Database of all lithic artefacts analysed in this article. 